\title{
New constraints on the exhumation history of the western Tauern Window (European Alps) from thermochronology, thermokinematic modeling, and topographic analysis
}

\author{
Reinhard Wolff ${ }^{1}$ (D) $\cdot$ Ralf Hetzel $^{1} \cdot$ István Dunkl $^{2} \cdot$ Aneta A. Anczkiewicz $^{3}$
}

Received: 12 April 2021 / Accepted: 22 July 2021 / Published online: 7 August 2021

(c) The Author(s) 2021

\begin{abstract}
The Brenner normal fault bounds the Tauern Window to the west and accommodated a significant portion of the orogenparallel extension in the Eastern Alps. Here, we use zircon (U-Th)/He, apatite fission track, and apatite (U-Th)/He dating, thermokinematic modeling, and a topographic analysis to constrain the exhumation history of the western Tauern Window in the footwall of the Brenner fault. ZHe ages from an E-W profile (parallel to the slip direction of the fault) decrease westwards from $\sim 11$ to $\sim 8 \mathrm{Ma}$ and suggest a fault-slip rate of $3.9 \pm 0.9 \mathrm{~km} / \mathrm{Myr}$, whereas AFT and AHe ages show no spatial trends. ZHe and AFT ages from an elevation profile indicate apparent exhumation rates of $1.1 \pm 0.7$ and $1.0 \pm 1.3 \mathrm{~km} / \mathrm{Myr}$, respectively, whereas the AHe ages are again spatially invariant. Most of the thermochronological ages are well predicted by a thermokinematic model with a normal fault that slips at a rate of $4.2 \mathrm{~km} / \mathrm{Myr}$ between 19 and $\sim 9 \mathrm{Ma}$ and produces $35 \pm 10 \mathrm{~km}$ of extension. The modeling reveals that the spatially invariant AHe ages are caused by heat advection due to faulting and posttectonic thermal relaxation. The enigmatic increase of $\mathrm{K}-\mathrm{Ar}$ phengite and biotite ages towards the Brenner fault is caused by heat conduction from the hot footwall to the cooler hanging wall. Topographic profiles across an $\mathrm{N}-\mathrm{S}$ valley in the fault footwall indicate $1000 \pm 300 \mathrm{~m}$ of erosion after faulting ceased, which agrees with the results of our thermokinematic model. Valley incision explains why the Brenner fault is located on the western valley shoulder and not at the valley bottom. We conclude that the ability of thermokinematic models to quantify heat transfer by rock advection and conduction is crucial for interpreting cooling ages from extensional fault systems.
\end{abstract}

Keywords European Alps · Tauern Window · Thermochronology · Thermokinematic modeling

\section{Introduction}

Low-temperature thermochronological data record the cooling history of rocks on their way to the Earth's surface and are routinely used to quantify rates of rock exhumation and slip rates of normal faults (e.g., Fitzgerald et al. 1993; Foster and John 1999; Brady 2002; Brichau et al. 2010; Buscher

Reinhard Wolff

rwolff@uni-muenster.de

1 Institut für Geologie und Paläontologie, Westfälische Wilhelms-Universität Münster, Corrensstraße 24, 48149 Münster, Germany

2 Institut für Sedimentologie und Umweltgeologie, Universität Göttingen, Goldschmidtstr. 3, 37077 Göttingen, Germany

3 Institute of Geological Sciences, Polish Academy of Sciences, Senacka 1, 31-002 Kraków, Poland et al. 2013). When determining rates of faulting and exhumation from thermochronological data, it is important to consider temporal changes of the temperature field in the crust, because faulting and erosion cause advection of hot rocks towards the Earth's surface, which increases the geothermal gradient (Stüwe et al. 1994; Ketcham 1996, 2005; Batt and Braun 1997; Mancktelow and Grasemann 1997; Braun 2016). For normal faults, the syntectonic conduction of heat from the exhuming footwall into the cooler hanging wall should lead to enhanced cooling of the footwall block near the fault; an effect that may be fortified by the circulation of fluids (Ehlers and Chapmann 1999; Wawrzyniec et al. 1999; Tagami 2005; Ault and Selverstone 2008; Luijendijk 2019). As a result, cooling ages in the footwall are expected to increase towards the fault, although this effect has rarely been investigated with thermochronological data (Dunkl et al. 1998; Ehlers et al. 2001; Seward et al. 2009). When faulting and heat advection stop, heat conduction 
during thermal relaxation decreases the geothermal gradient in the entire footwall block and may cause rapid posttectonic cooling (Braun 2016; Wolff et al. 2020). Owing to the processes of syntectonic heat advection and posttectonic thermal relaxation, it is essential to apply thermokinematic modeling to derive fault-slip histories from thermochronological data (e.g., Ketcham 1996; Campani et al. 2010; Styron et al. 2013; McCallister et al. 2014; Wolff et al. 2019).

The position of active faults in mountain belts is often marked by valleys, as brittle fault rocks such as fault gouge and cataclasite have relatively higher erodibility than less deformed rocks adjacent to the fault (e.g., Koons et al. 2012). This is particularly important for normal faults, where the process of footwall uplift causes a relative downward movement of the hanging wall, which causes the flow of water or ice to be focused at or near the fault trace. Hence, faults may control the pathways along which sedimentary material is transported from the mountains towards sedimentary basins in the foreland.

In this study, we present new structural, topographic, and thermochronological data from the Brenner normal fault in the European Alps. These data complement a recent study that applied thermokinematic modeling to a thermochronological data set from a vertical transect (including a 1000-m-long drill core) and showed that posttectonic thermal relaxation affected the rock cooling history in the fault footwall (Wolff et al. 2020). Our new data and thermokinematic modeling provide improved constraints on the evolution of the Brenner normal fault, the cooling history of its footwall (the western Tauern Window), and the amount of erosion and valley incision after faulting stopped.

\section{Geological setting}

The European Alps formed during two orogenic cycles that took place in the Cretaceous and Cenozoic (e.g., Trümpy 1960; Frisch 1978; Froitzheim et al. 1994; Schmid et al. 1996). The first phase of mountain building was related to the closure of the Meliata ocean between the Late Jurassic and the Early Cretaceous, whereas the second phase was caused by the southeastward subduction of the Penninic ocean and the subsequent collision between the European and Adriatic plates (e.g., Stampfli 2000; Froitzheim et al. 1994; Schmid et al. 2004; Handy et al. 2010). The Penninic ocean consisted of a southern and a northern branch (i.e., the Piedmont-Ligurian ocean adjacent to the Adriatic plate and the Valais ocean near the European plate), which were separated by the Brianconnais microcontinent (Trümpy 1960; Frisch 1978; Froitzheim and Manatschal 1996; Stampfli 2000). After the closure of the Penninic oceans, the European passive margin entered the subduction zone in the Early Eocene, which caused nappe stacking and crustal thickening (e.g., Termier 1903; Schmid et al. 1996; Bousquet et al. 2008; Handy et al. 2010). The presence of Tertiary intrusions and mafic dykes along the Periadriatic Line (Fig. 1) has been interpreted to indicate the breakoff of the European slab in the Early Oligocene, because the intrusive rocks have a geochemical affinity to the mantle and formed mainly between 34 and $24 \mathrm{Ma}$, with few intrusive rocks being as old as 42-38 Ma (Bögel 1975; Exner 1976; Laubscher 1983a; von Blanckenburg and Davies 1995; Kissling et al. 2006). During the following plate convergence, the southeastward subduction of the European passive margin continued west of the Tauern Window, whereas east of the window, geophysical data seem to indicate a northeastward subduction of the Adriatic plate beneath Europe (e.g., Lippitsch et al. 2003; Kissling et al. 2006; Kästle et al. 2020 and references therein). In the area of the Tauern Window (Fig. 1), recent geophysical data suggest that the subducted European slab is detached from the orogenic crust and dips steeply to the NNE (Handy et al. 2021; Paffrath et al. 2021). A recent switch in subduction polarity with a northward subduction of the Adriatic plate may have occurred here in the Miocene (Kästle et al. 2020; Eizenhöfer et al. 2021).

During post-collisional plate convergence and related crustal thickening, the formation of normal faults and conjugate strike-slip faults led to orogen-parallel extension of the Alps and the formation of tectonic windows (Fig. 1) (e.g., Tollmann 1962; Ratschbacher et al. 1989; Frisch et al. 1998, 2000; Neubauer et al. 1999; Lammerer and Weger 1998; Schmid et al. 2013). In the Central Alps, the Simplon normal fault aided the exhumation of the Lepontine dome (Campani et al. 2010). In the Eastern Alps, the Engadine and Tauern Windows (Fig. 1) expose European and Penninic units, which were underthrusted beneath the Adriatic plate represented by the Austroalpine nappes (Frisch 1974; Laubscher 1983b; Ratschbacher et al. 1990; Lammerer and Weger 1998; Dal Piaz et al. 2003). The Tauern Window is $150 \mathrm{~km}$ long and bounded by the Brenner and Katschberg normal faults in the west and east, respectively (Fig. 2) (Genser and Neubauer 1988; Ratschbacher et al. 1991; Fügenschuh et al. 1997; Rosenberg and Garcia 2011; Scharf et al. 2013). North and south of the window, conjugate strike-slip faults accommodated orogen-parallel extension (Figs. 1 and 2) (Behrmann and Frisch 1990; Ratschbacher et al. 1991; Neubauer et al. 1995; Frisch et al. 2000; Linzer et al. 2002; Scharf et al. 2013).

The metamorphic rocks of the Tauern Window comprise Variscan basement and Mesozoic sediments derived from the distal European margin and the Penninic nappes, respectively (Fig. 2). The Variscan basement, including PermoCarboniferous intrusions, and its Upper Carboniferous to Permian sedimentary cover form a crustal-scale duplex called Venediger Duplex (Selverstone 1988; Lammerer and Weger 1998; Lammerer et al. 2008). The Venediger Duplex 


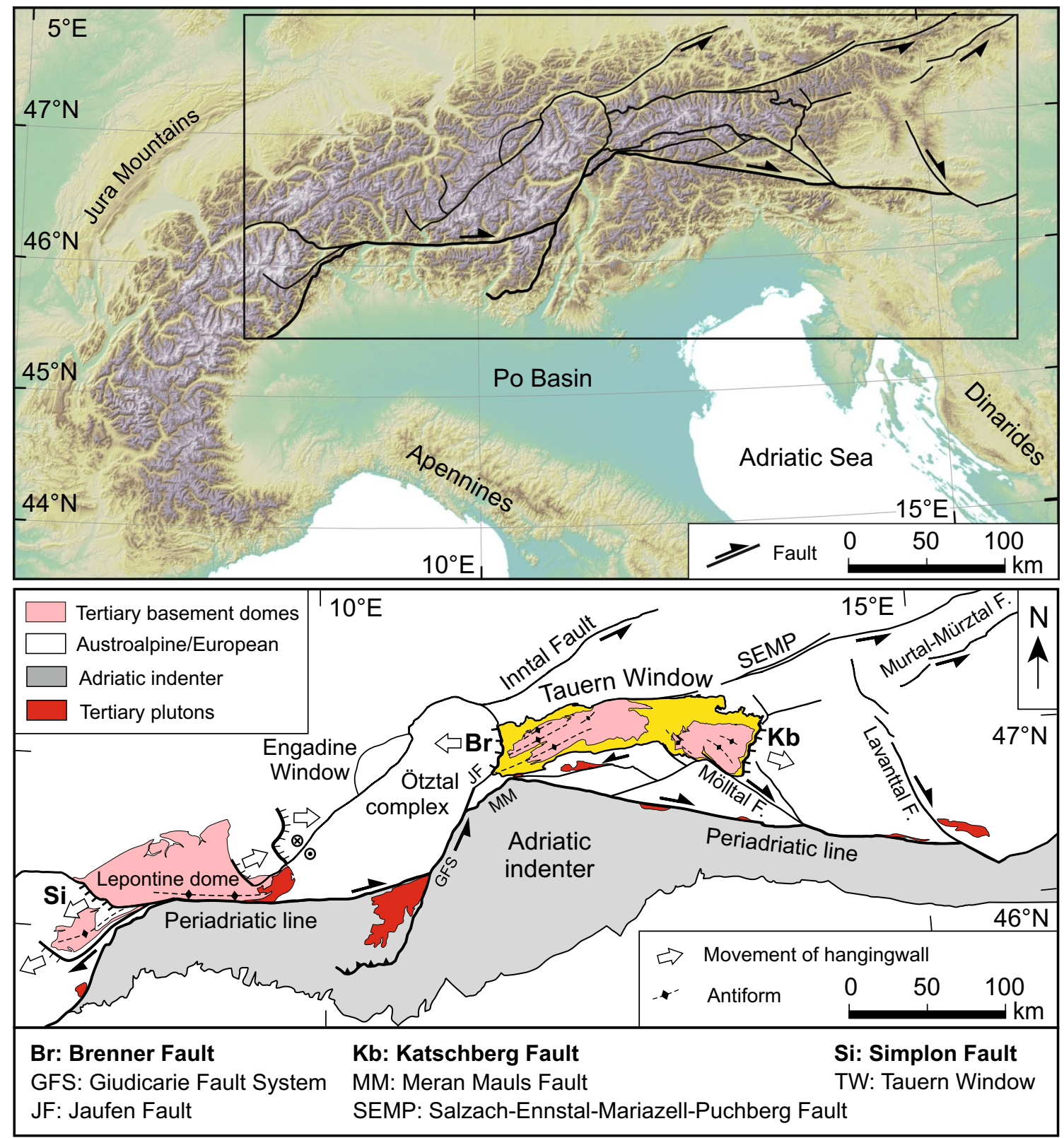

Fig. 1 Topographic map of the European Alps with rectangle indicating the position of the tectonic map shown below. The tectonic map shows the Tertiary fault systems and the position of Tertiary basement domes (modified after Handy et al. 2005). The basement domes of the Tauern Window are bounded by the Brenner and Katschberg normal faults, respectively. White arrows indicate the extension direction for the different normal faults

nappe comprises calcareous micaschists intercalated with greenschists and amphibolites, whereas the Matrei zone is an imbricated unit or a mélange zone with Bündner schisttype sediments and Austroalpine olistolithes (Frisch 1979; Handy et al. 2010; Schmid et al. 2013). During subduction, the rocks of the Lower Schieferhülle and Upper Schieferhülle experienced peak pressures of 1.0-1.1 GPa and 0.7-0.8 $\mathrm{GPa}$, respectively (Selverstone 1985). After the juxtaposition of these units during duplex formation, the Lower and Upper Schieferhülle experienced Barrovian metamorphic Window are lithologically heterogeneous; the Glockner 


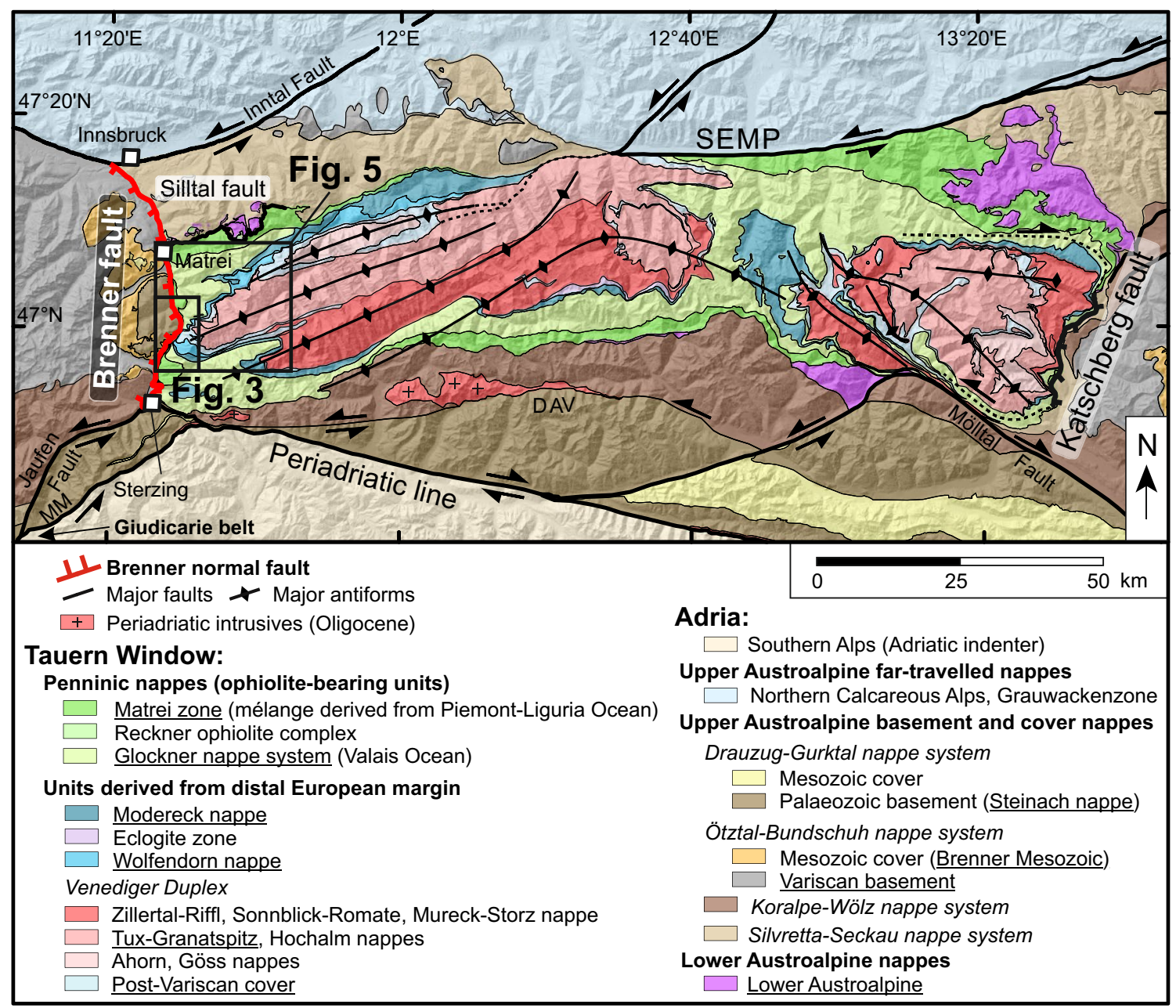

Fig. 2 Tectonic map of the Tauern Window (modified after Schmid et al. 2013). Tectonic units that are underlined in the legend appear in Fig. 3. $D A V$ Defreggen-Antholz-Vals fault, MM Meran-Mauls fault, SEMP Salzach-Ennstal-Mariazell-Puchberg fault

conditions with peak temperatures of $500-600{ }^{\circ} \mathrm{C}$ and pressures of 0.7-1.0 GPa (Selverstone et al. 1984; Selverstone 1985). Further shortening led to large-scale upright folding and the formation of two sub-domes in the western and eastern Tauern Window, respectively (Rosenberg et al. 2004; Schuster et al. 2004; Cliff et al. 2015). Oligocene-to-early Miocene apatite $\mathrm{U}-\mathrm{Pb}$ ages from the Venediger Duplex record continuous cooling during dome formation (Schneider et al. 2015).

\section{The Brenner normal fault system}

The 40-km-long Brenner fault system extends from Innsbruck to Sterzing (Fig. 2). Its northern part between Innsbruck and Matrei is developed as a brittle normal fault without mylonites and referred to as Silltal fault (Schmidegg 1964; Fügenschuh et al. 1997). Farther south, the Brenner fault sensu stricto between Matrei and Sterzing comprises west-dipping mylonites with a thickness of $\sim 1.5 \mathrm{~km}$ and a brittle normal fault at the top of the mylonites (Behrmann 1988; Selverstone 1988; Fügenschuh et al. 1997; Rosenberg and Garcia 2011; Rosenberg et al. 2018). In the hanging wall of the Brenner fault occur Austroalpine basement and cover nappes (Fig. 2), which include the Variscan basement of the Ötztal complex and its Mesozoic cover (Brenner Mesozoic), as well as the Paleozoic basement rocks of the Steinach nappe and its Mesozoic cover (Schmidegg 1964; Froitzheim 1994; Fügenschuh et al. 2000).

Thermochronological data of samples from the western Tauern Window indicate that cooling during the Miocene is related to normal faulting and footwall exhumation along the Brenner fault (Grundmann and Morteani 1985; von Blanckenburg et al. 1989; Fügenschuh et al. 1997; Most 2003; Bertrand et al. 2017). A thermokinematic modeling study that used new zircon and apatite (U-Th)/He (ZHe, AHe, respectively) as well as apatite fission-track (AFT) ages from a near-vertical transect (including a 1000-m-long drill 
core) showed that the Brenner fault was active from $19 \pm 2$ to $8.8 \pm 0.4 \mathrm{Ma}$ at a slip rate of $4.2 \pm 0.9 \mathrm{~km} / \mathrm{Myr}$ (Wolff et al. 2020). Farther west in the hanging wall, AFT and ZFT ages from the Ötztal-Stubai Complex and the Brenner Mesozoic indicate an older phase of cooling between $\sim 90$ and $\sim 60 \mathrm{Ma}$ (Fügenschuh et al. 2000). Samples from the Steinach nappe, collected only $0.5-3.0 \mathrm{~km}$ west of the Brenner fault, yielded $\mathrm{ZHe}$ ages between $71 \pm 10$ and $63 \pm 7 \mathrm{Ma}$, indicating that their post-Eoalpine cooling was not affected by the Miocene activity of the Brenner normal fault (Lünsdorf et al. 2012).

\section{Structural data and topographic analysis}

In the central part of the Brenner fault, the mylonites in the footwall consist of strongly deformed calc-micaschists (Bündner schists) of the Matrei Zone and mylonitic calcphyllites of the Glockner nappe (Fig. 3A). The mylonites contain quartz, K-feldspar, calcite, chlorite with accessory muscovite, biotite, epidote, and rutile. Quartz grains show bulging and subgrain rotation recrystallization typical for low-grade metamorphic conditions. Together with the occurrence of chlorite, these microstructures indicate deformation during retrograde greenschist-facies metamorphic conditions. The well-developed mylonitic foliation dips gently to the west $\left(10^{\circ}-36^{\circ}\right)$, and the stretching lineation plunges gently to the WSW to WNW $\left(255^{\circ}-290^{\circ}\right)$ (Fig. 3). Asymmetric extensional shear bands indicate a consistent top-to-the-W shear sense, as reported in earlier studies, which also showed that quartz-c-axis fabrics formed during top-to-the-W shearing (Behrmann 1988; Selverstone 1988).

Adjacent to the Brenner fault, both Austroalpine hanging wall rocks and footwall mylonites are affected by intense brittle deformation. Dolomites of the Mesozoic cover of the Ötztal complex and quartzphyllites of the Steinach nappe are intensely brecciated. Likewise, the mylonites near the top of the Brenner shear zone are overprinted by brittle faulting. These normal faults dip W to SW at angles between $20^{\circ}$ and $50^{\circ}$, and contain layers of fault gouge with a thickness of up to $0.4 \mathrm{~m}$. It is noteworthy that these brittle faults are either parallel or only slightly steeper than the mylonitic foliation (Fig. 4A, B). This spatial relation is typical for low-angle normal fault systems that progressively exhume mid-crustal rocks in their footwalls.

It is important to note that the trace of the Brenner fault is not situated at the bottom of the N-S valley of the Sill and Eisack rivers, but on the western shoulder of this valley (Figs. 3 and 4C). Five profiles, P1-P5, across the valley between the villages Gries am Brenner and Sterzing show the presence of low-relief surfaces dipping gently $\left(10^{\circ}-25^{\circ}\right)$ to the west (Fig. 3D). The Brenner fault runs along the western margin of these low-relief surfaces. Near profile P4, a minor normal fault is located east of the main Brenner fault.
The absolute elevation of the low-relief surfaces is highest on profile P3 (2020 m a.s.l.) and decreases towards the north and south to $\sim 1700 \mathrm{~m}(\mathrm{P} 1)$ and $\sim 1750 \mathrm{~m}$ (P5), respectively. The position of the Brenner fault several hundred meters above the main valley suggests that faulting must have ceased before the incision of the valley, and is consistent with the lack of crustal seismicity in the western Tauern Window, which indicates that the Brenner fault is not active (Reiter et al. 2018). The results of thermokinematic modeling by Wolff et al. (2020) indicate that normal faulting stopped $8.8 \pm 0.4 \mathrm{Ma}$ ago. The envisioned paleotopography at the end of faulting is shown in Fig. 3C, which explains how we determine minimum and maximum amounts of valley incision after faulting. A minimum amount can be estimated from the vertical distance between the valley bottom and the highest points on the low-relief surfaces (Fig. 3C). This distance ranges from $340 \mathrm{~m}$ on profile 1 to $630 \mathrm{~m}$ on profile 3 (Fig. 3D). A maximum amount of incision can be obtained by extrapolating the Brenner fault towards the east assuming a fault dip of $35^{\circ}$ (dashed lines in Fig. 3D). This approach leads to maximum incision values between 750 and $1200 \mathrm{~m}$.

\section{Sampling and analytical methods}

We employed ZHe, AHe, and AFT thermochronology to further constrain the cooling history of the Brenner normal fault (Table 1). Along a $\sim 16 \mathrm{~km}$ long WSW-ESE profile, which extends from the Brenner fault (near Brennerbad) along a prominent mountain ridge to Olperer mountain (Fig. 5), we collected four orthogneiss samples (17A15, 17A14, 17A22, and 17A19) that complement the five samples dated by Wolff et al. (2020). The elevation of the nine samples along this profile increases eastward from 1342 to $3236 \mathrm{~m}$ (Table 1). On the northern and southern flanks of Olperer mountain, we took four orthogneiss samples (16A19, 17A20, 17A21, and 17A25; Table 1). Together with the easternmost sample of the WSW-ENE profile (17A19), these samples cover a vertical distance of $\sim 1.5 \mathrm{~km}$. Close to the Brenner fault, we collected another six samples at two sites, A and B, located west of Brenner lake and west of Brennerbad, respectively (Fig. 3B). At site A, two samples that are $\sim 2 \mathrm{~m}$ apart were collected in the footwall close to the fault, whereas a third sample was taken $100 \mathrm{~m}$ farther west in the hanging wall. At site B, where a second normal fault occurs $\sim 400$ m east of the Brenner fault (Fig. 3A), we took three samples between the two faults over a distance of $40 \mathrm{~m}$.

For (U-Th)/He thermochronology, we selected euhedral zircon and apatite crystals without inclusions by handpicking after heavy-liquid separation. The single crystals were wrapped in $1 \times 1 \mathrm{~mm}$-sized platinum capsules and degassed in high vacuum by heating with an infrared diode 
Fig. 3 A Geological map of the central part of the Brenner normal fault (simplified after Schmid et al. 2013 and Rockenschaub and Nowotny 2009). Position of Brenner fault after Rosenberg and Garcia (2011). The hanging wall comprises the Ötztal complex and its Mesozoic cover as well as the Steinach nappe, whereas the footwall includes Penninic and Subpenninic nappes as well as part of the Lower Austroalpine nappe. B Shaded relief image of the area shown in A. The Brenner fault runs along the western margin of a gently dipping low-relief surface. Straight lines indicate position of profiles $\mathrm{P} 1-$ P5 shown in D. Image is based on TanDEM-X digital elevation data with a resolution of $8 \mathrm{~m}$. C Sketch illustrating our approach to estimate the amount of valley incision after faulting from the inferred paleotopography and a fault dip of $35^{\circ}$. A minimum estimate is given by the vertical distance between the valley bottom and the highest point on the low-relief surface in the fault footwall. The elevation difference between the paleo-valley and the present-day surface yields the maximum amount of incision. D Geological profiles $\mathrm{P} 1-\mathrm{P} 5$ across the valley in the footwall of the Brenner fault (profiles have no vertical exaggeration). The vertical distance between valley bottom and valley shoulder is a minimum for the amount of valley incision after faulting stopped. The dashed lines approximate the paleotopography at the end of faulting and provide a maximum amount of incision
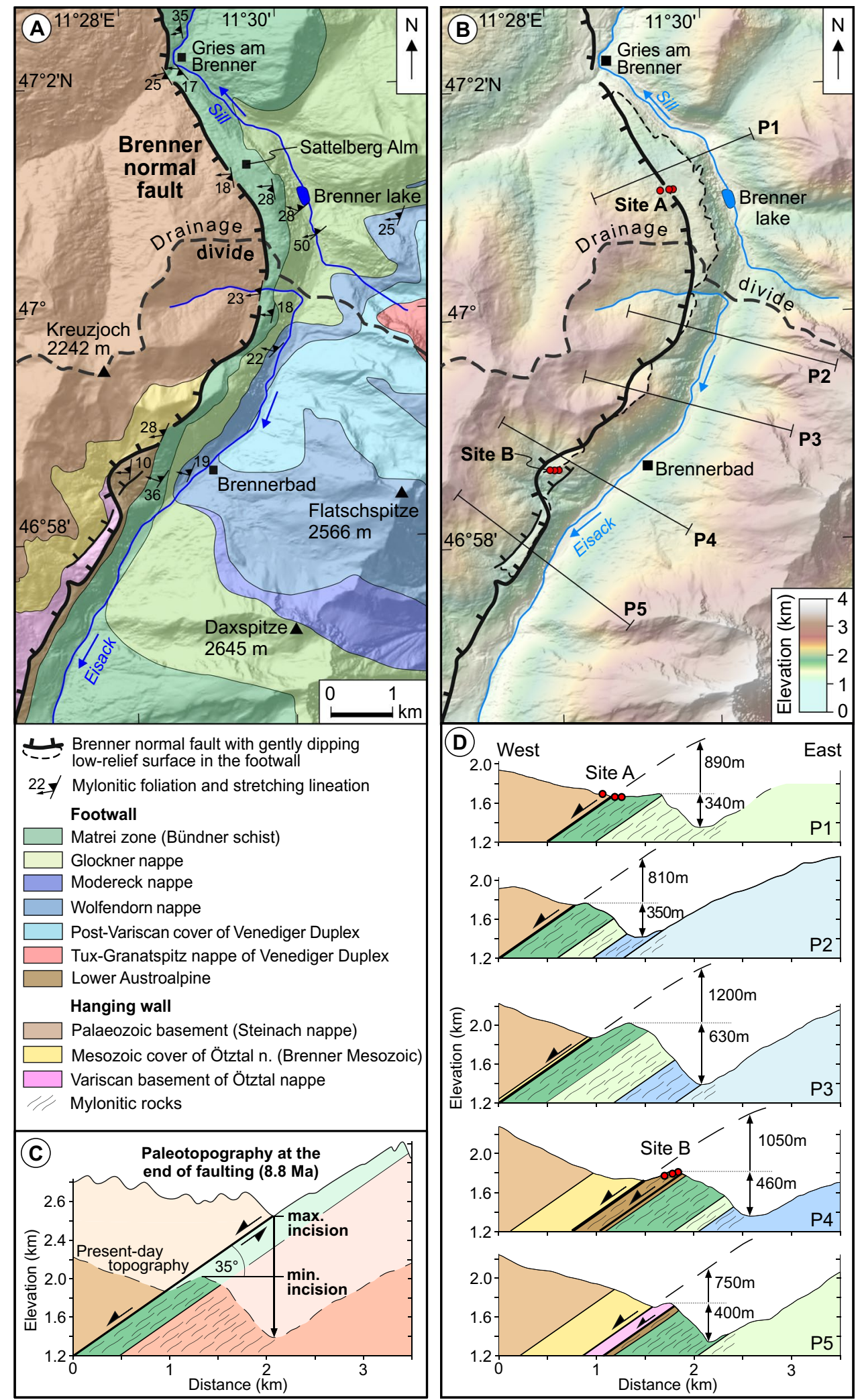

laser at the GÖochron Laboratories, University of Göttingen. The extracted gas was purified using an SAES Ti-Zr getter at $450{ }^{\circ} \mathrm{C}$ and spiked with ${ }^{3} \mathrm{He}$. The chemically inert noble gases and a minor amount of other trace gases were then expanded into a Hiden triple-filter quadrupole mass spectrometer equipped with an ion counting detector. 

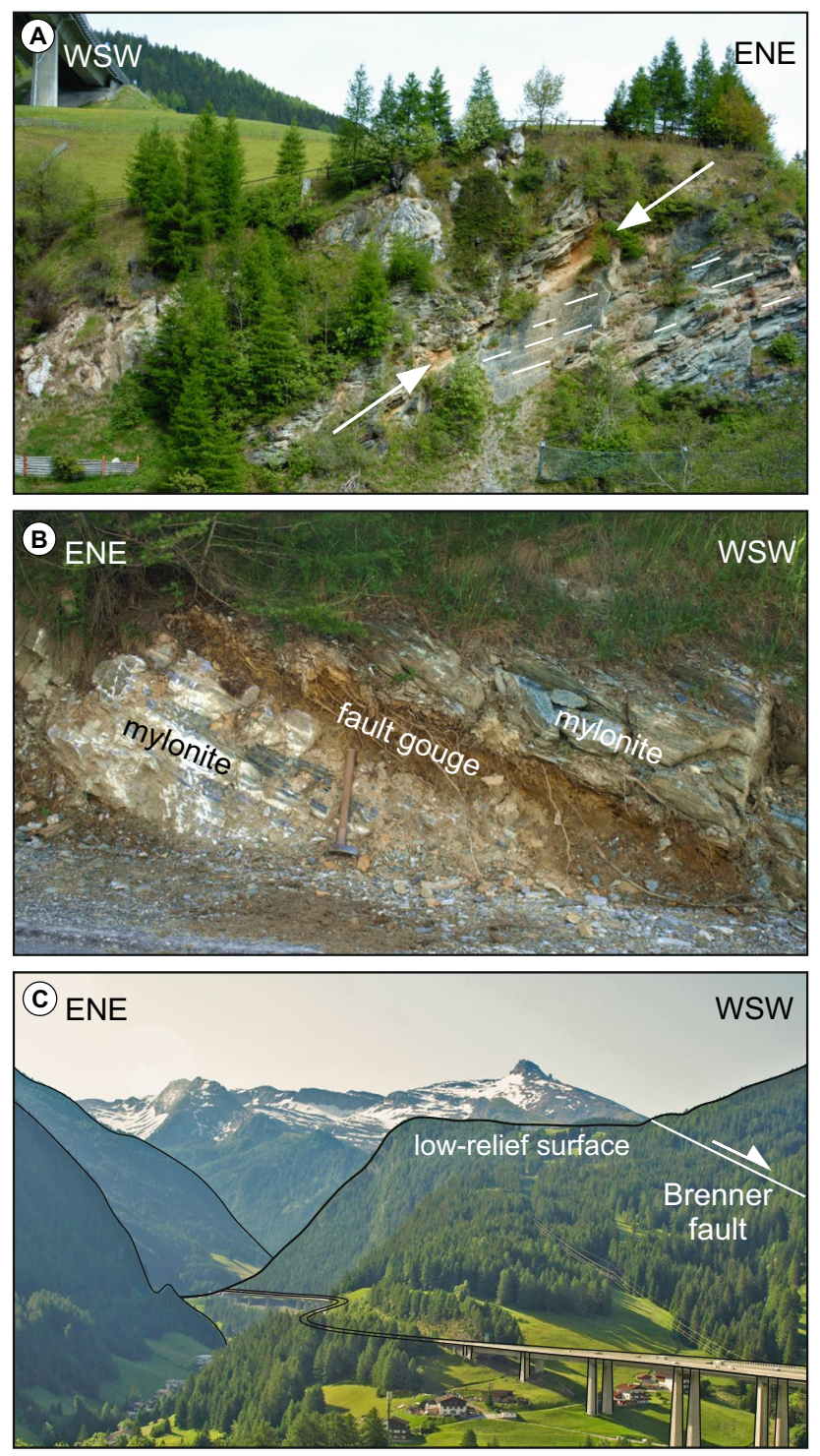

Fig. 4 Pictures of normal fault near Gries am Brenner (see Fig. 5 for location of photographs). A Brittle normal fault (white arrows) with $0.4 \mathrm{~m}$-thick fault gouge dipping $\sim 35^{\circ}$ to the SW. The fault is slightly steeper than the mylonitic foliation in the calc-micaschists $(150 / 27$ $\mathrm{SW})$. Outcrop is $\sim 40 \mathrm{~m}$ wide. B Brittle normal fault with brown fault gouge that is parallel to the foliation in adjacent calc-mylonites. Fault dips $\sim 25^{\circ} \mathrm{SW}$. Hammer is $53 \mathrm{~cm}$ long. C Photograph of the low-relief surface in the footwall of the Brenner fault, which forms a prominent shoulder above the steep valley. View direction is to the SSE

Crystals were checked for complete degassing of helium by sequential reheating and helium measurement. Following degassing, crystals were retrieved from the gas extraction line, unpacked, and spiked with calibrated ${ }^{230} \mathrm{Th}$ and ${ }^{233} \mathrm{U}$ solutions and dissolved in pressurized teflon bombs at $220{ }^{\circ} \mathrm{C}$ using distilled $48 \% \mathrm{HF}+65 \% \mathrm{HNO}_{3}$ for 5 days, or in $4 \% \mathrm{HNO}_{3}$ for 1 day, for zircons and apatites, respectively. Spiked solutions were analyzed by the isotope dilution method using an iCAP Q ICP-MS equipped with an
APEX micro-flow nebulizer. Crystal shape parameters were determined by multiple microphotographs and used to determine correction factors for alpha-ejection (Farley et al. 1996) with the constants of Hourigan et al. (2005).

Apatite fission track dating by the external detector method (Gleadow 1981) was carried out at the Institute of Geological Sciences, Polish Academy of Sciences in Krakow (Poland). The selected apatite crystals were embedded in epoxy resin and polished using $\mathrm{Al}_{2} \mathrm{O}_{3}$ suspensions. Then, they were etched in $5 \mathrm{~N} \mathrm{HNO}_{3}$ at a temperature of $21^{\circ} \mathrm{C}$ for $20 \mathrm{~s}$ to reveal spontaneous fission tracks (Zaun and Wagner 1985; Donelick et al. 1999). Neutron irradiation of samples, age standards (Fish Canyon Tuff, Durango and Mount Dromedary apatites), and CN5 glass dosimeter was performed at the TRIGA reactor (Oregon State University, USA). After irradiation, the induced fission tracks in the mica detectors were revealed by etching in $40 \% \mathrm{HF}$ for $45 \mathrm{~min}$. Track counting and length measurements were made with a NIKON Eclipse E-600 microscope computer-controlled stage system (Dumitru 1993) with $1250 \times$ magnification. Calculations and plots were done with the software TRACKKEY (Dunk1 2002). The fission-track ages were determined by the zeta method (Hurford and Green 1983) using age standards listed in Hurford (1998). The error was calculated following the procedure of Green (1981). The fission-track annealing kinetics was assessed by measuring the etch pit diameters (Dpar) (Burtner et al. 1994).

\section{Results of thermochronology and thermokinematic modeling}

In this section, we describe our thermochronological data set and the thermokinematic model (Fig. 6A) that we use to predict the cooling ages obtained from the three different thermochronometers (ZHe, AFT, and AHe). The single-crystal $\mathrm{ZHe}$ and $\mathrm{AHe}$ ages and the unweighted average ages for all samples (including those of Wolff et al. 2020) are reported in Tables 2 and 3. The radiation damage densities of the apatite and zircon crystals range from $1.6 \times 10^{13}$ to $3.4 \times 10^{15}$ alpha decay events/gram and from $6.5 \times 10^{15}$ to $2.6 \times 10^{17}$ alpha decay events/gram, respectively. These ranges are well below the thresholds for a damage-induced decrease of closure temperatures (Flowers et al. 2009; Gautheron et al. 2009; Guenthner et al. 2013). The AFT data are given in Table 4. All AFT samples passed the Chi-square test and are therefore considered to form one age population. In the following, we describe the cooling ages obtained from the WSW-ENE profile and the age-elevation profile at Olperer mountain, followed by the age results at the sites A and B near the Brenner fault. 
Table 1 Coordinates of sampling locations at the Brenner fault
Fig. 5 Shaded relief image of the study area with sample locations. Grey dots indicate position of photos in Fig. 4. Samples 17A9 to 17A19 along ridge crest are shown in Fig. 7. Samples in black rectangle near Olperer mountain are shown in Fig. 8. Sites A and B are shown in Fig. 9. Elevation profile and drill core position of Wolff et al. (2020) are shown by black line. Image is based on TanDEM-X digital elevation data with a resolution of $8 \mathrm{~m}$

\begin{tabular}{cccll}
\hline Sample number & Latitude $\left({ }^{\circ} \mathrm{N}\right)$ & Longitude $\left({ }^{\circ} \mathrm{E}\right)$ & Elevation $(\mathrm{m})$ & Sample lithology \\
\hline WSW-ENE profile and elevation profile near Olperer mountain & & \\
17A9* & 46.9664 & 11.4690 & 1342 & Mylonitic schist \\
17A11* & 46.9715 & 11.5032 & 1975 & Calcschist \\
17A17* & 46.9878 & 11.5465 & 2557 & Calcschist \\
17A16* & 46.9904 & 11.5541 & 2606 & Orthogneiss \\
17A15 & 46.9929 & 11.5651 & 2737 & Orthogneiss \\
17A14 & 46.9947 & 11.5737 & 2629 & Orthogneiss \\
17A13* & 46.9971 & 11.5813 & 2721 & Orthogneiss \\
17A22 & 47.0375 & 11.6496 & 2958 & Orthogneiss \\
17A19 & 47.0617 & 11.6804 & 3236 & Orthogneiss \\
16A19 & 47.0337 & 11.6983 & 1781 & Orthogneiss \\
17A20 & 47.0768 & 11.6723 & 2605 & Orthogneiss \\
17A21 & 47.0975 & 11.6737 & 1745 & Orthogneiss \\
17A25 & 47.0439 & 11.6898 & 2416 & Orthogneiss \\
Site A & & & & \\
19A9 & 47.0182 & 11.4925 & 1661 & Mylonitic schist \\
19A10 & 47.0182 & 11.4925 & 1662 & Mylonitic schist \\
19A12 & 47.0183 & 11.4906 & 1693 & Quarzphyllite \\
Site B & & & & Mylonitic schist \\
19A14 & 46.9780 & 11.4673 & 1709 & Mylonitic schist \\
19A15 & 46.9780 & 11.4671 & 1703 & \\
19A16 & 46.9780 & 1.4664 & & \\
\hline Samples & & & & \\
\end{tabular}

Samples with asterisks are from Wolff et al. (2020)

${ }^{\text {a }}$ Sample locations are shown in Fig. 5

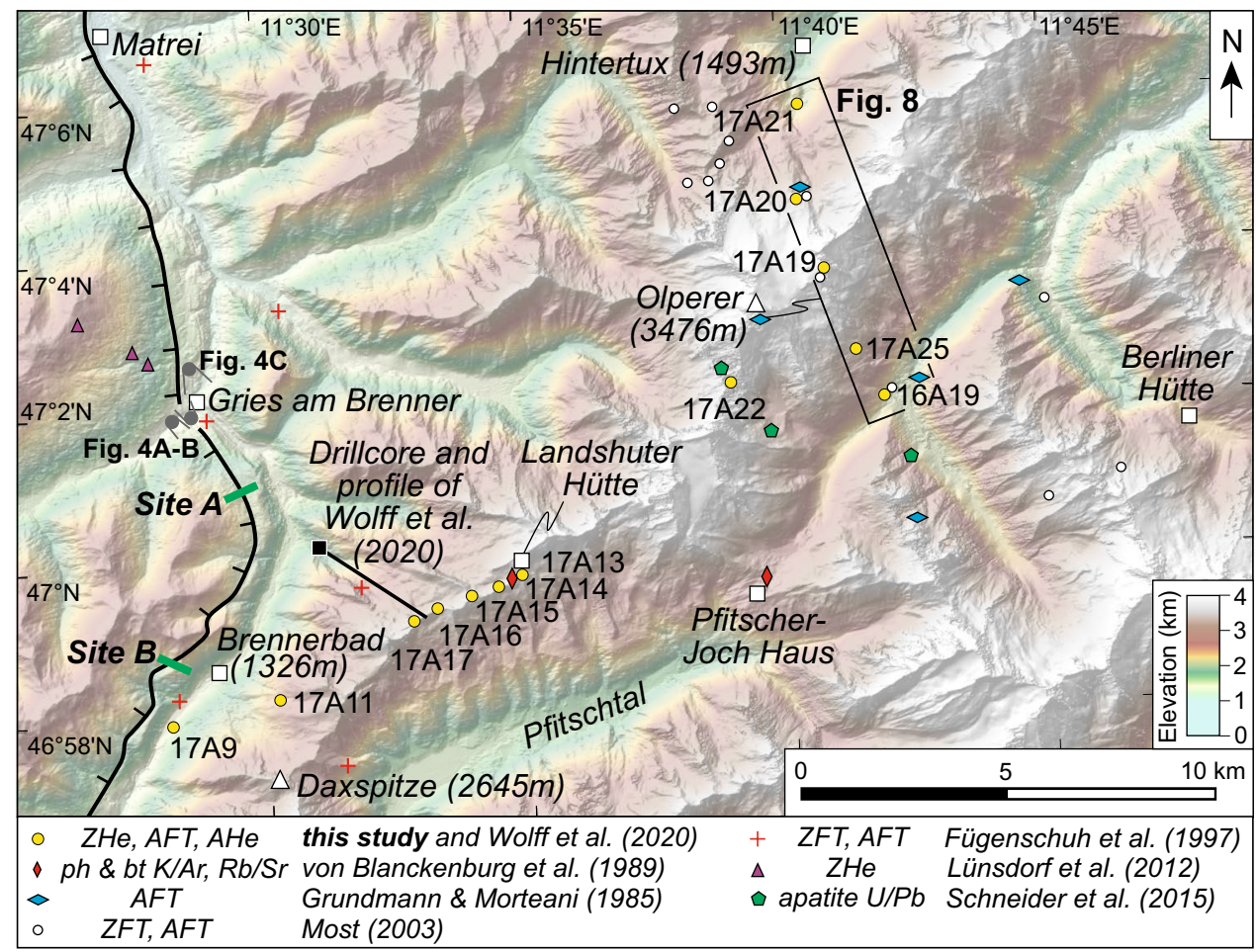




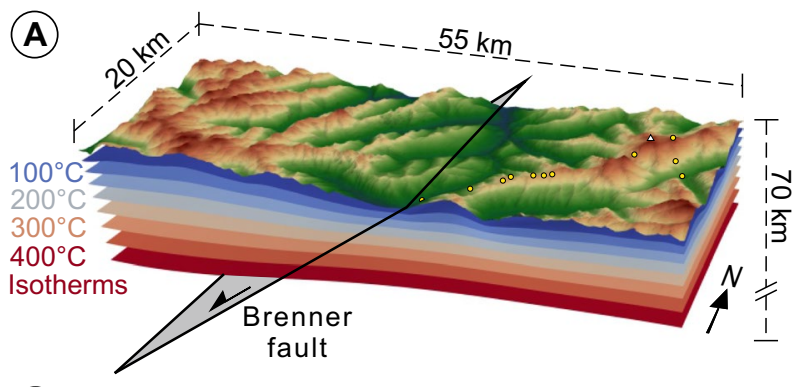

(B)
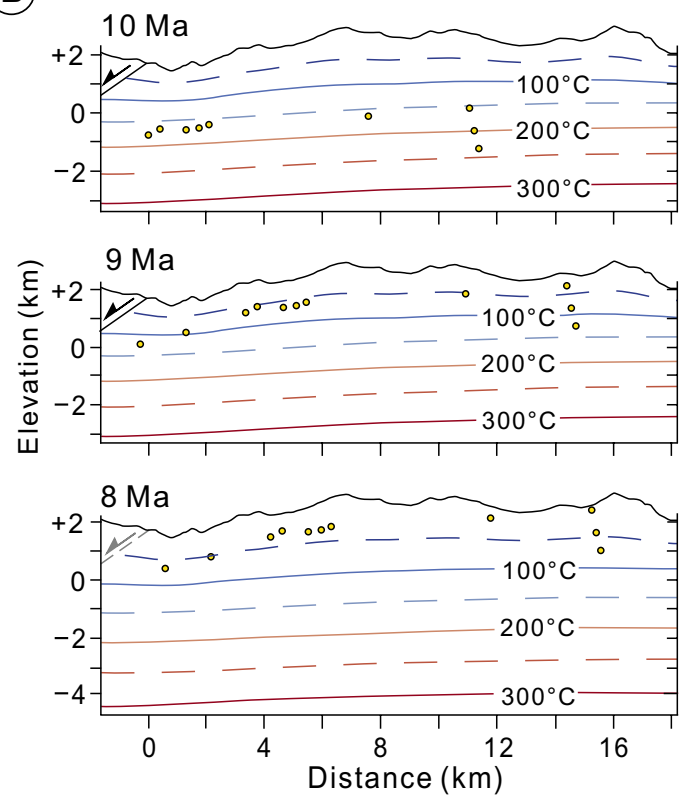

Fig. 6 A Three-dimensional view of the thermokinematic model used in this study. The entire model is $70 \mathrm{~km}$ thick (only the upper part is shown here). The planar normal fault is active between 19.0 and 8.8 Ma. The isotherms (blue to red surfaces with a spacing of $50{ }^{\circ} \mathrm{C}$ ) are shown at $10 \mathrm{Ma}$ model time. Yellow dots are sample positions. B The temperature evolution in the fault footwall is shown at model times of 10,9 , and $8 \mathrm{Ma}$. Heat advection due to normal faulting has shifted the isotherms in the fault footwall towards the surface, which causes rapid syntectonic cooling. When faulting stops at $8.8 \mathrm{Ma}$, the upper crust cools rapidly during thermal relaxation as can be seen by the downward shift of the isotherms between 9 and $8 \mathrm{Ma}$

\section{Profile in fault footwall and age-elevation profile near Olperer mountain}

The ZHe, AFT, and AHe ages of the nine samples collected along the mountain ridge in the footwall of the Brenner fault are shown in Fig. 7. The ZHe ages range from $7.9 \pm 0.3$ to $11.1 \pm 1.1 \mathrm{Ma}$ and show a trend of increasing ages towards the east, although there is considerable scatter in the data (Fig. 7B). This is the reason why a regression line in the age-versus-distance plot with an inverse slope of $6.9 \mathrm{~km} /$ Myr is not well defined $\left(R^{2}=0.4\right)$. A least-square regression (York 1966) through the ZHe ages yields a different inverse slope of $3.9 \pm 0.9 \mathrm{~km} / \mathrm{Myr}$. The AFT and AHe ages along the profile range from $7.3 \pm 2.2$ to $10.8 \pm 2.0 \mathrm{Ma}$ and from $8.5 \pm 0.3$ to $9.8 \pm 5.4 \mathrm{Ma}$, respectively. In contrast to the $\mathrm{ZHe}$ ages, neither the AFT ages (with their relatively large errors) nor the AHe ages show a significant correlation between cooling ages and distance to the Brenner fault (Fig. 7C, D). Owing to the relatively large errors of two He ages (ZHe age of sample 17A17 and AHe age of 17A19), it is not surprising that local age inversions occur along the profile.

The results from the elevation profile at Olperer mountain (see Fig. 5) are shown in Fig. 8. By adding published AFT ages (Grundmann and Morteani 1985; Most 2003; see rectangle in Fig. 5), we increased the vertical distance covered by the profile from 1.5 to $1.8 \mathrm{~km}$. The $\mathrm{ZHe}$ ages range between $8.6 \pm 1.3$ and $10.7 \pm 0.7 \mathrm{Ma}$ and least-square fitting yields a regression line with a slope of $1.1 \pm 0.7 \mathrm{~km} / \mathrm{Myr}$. For our AFT ages, we obtain a similar slope of $1.0 \mathrm{~km} / \mathrm{Myr}$, but with a large uncertainty of $\pm 1.3 \mathrm{~km} / \mathrm{Myr}$. If the AFT ages of Most (2003) and Grundmann and Morteani (1985) are included, the slope is only $0.5 \pm 0.1 \mathrm{~km} / \mathrm{Myr}$. The nominal AHe ages do not vary with elevation (three of the four AHe ages are $9.5 \mathrm{Ma}$ old), and therefore, it is not possible to derive a meaningful slope value.

Although thermochronological ages from normal fault footwalls are often used to estimate rates of faulting and exhumation (e.g., Brady 2002; Brichau et al. 2010; Buscher et al. 2013), geologically meaningful rates can only be obtained if the slopes of regression lines are well defined, and if the isotherms remained spatially and temporally invariant during the episode of faulting and exhumation recorded by the data. Thermokinematic modeling can be used to test whether these assumptions are met and can help to interpret age data in a meaningful way.

\section{Thermokinematic modeling}

To predict ZHe, AFT, and AHe cooling ages for the samples described in Sect. 6.1, we used the thermokinematic model of Wolff et al. (2020), which is based on the finite-element code PECUBE (Braun et al. 2012). To calculate ages with PECUBE, we used the same diffusion and annealing models as employed by Wolff et al. (2020). These are the diffusion model of Farley (2000) for AHe, the annealing model of Ketcham (2005) for AFT, and the diffusion model of Reiners et al. (2004) for ZHe. The latter was adjusted using a $D_{0} / a^{2}$ value of $37,8001 / \mathrm{s}$ and an activation energy of $168 \mathrm{~kJ} /$ mol to account for the rather low radiation damage of the zircon samples (cf. Guenthner et al. 2013). This model was able to predict the $\mathrm{ZHe}, \mathrm{AFT}$, and AHe cooling ages from a vertical profile close to the Brenner fault, which included a 1000-m-long drill core, within their uncertainties (see Fig. 5 for location of the profile and the drill core). The only difference of the current model to the one of Wolff et al. (2020) is the model size, which was increased to $55 \times 20 \mathrm{~km}$ to 


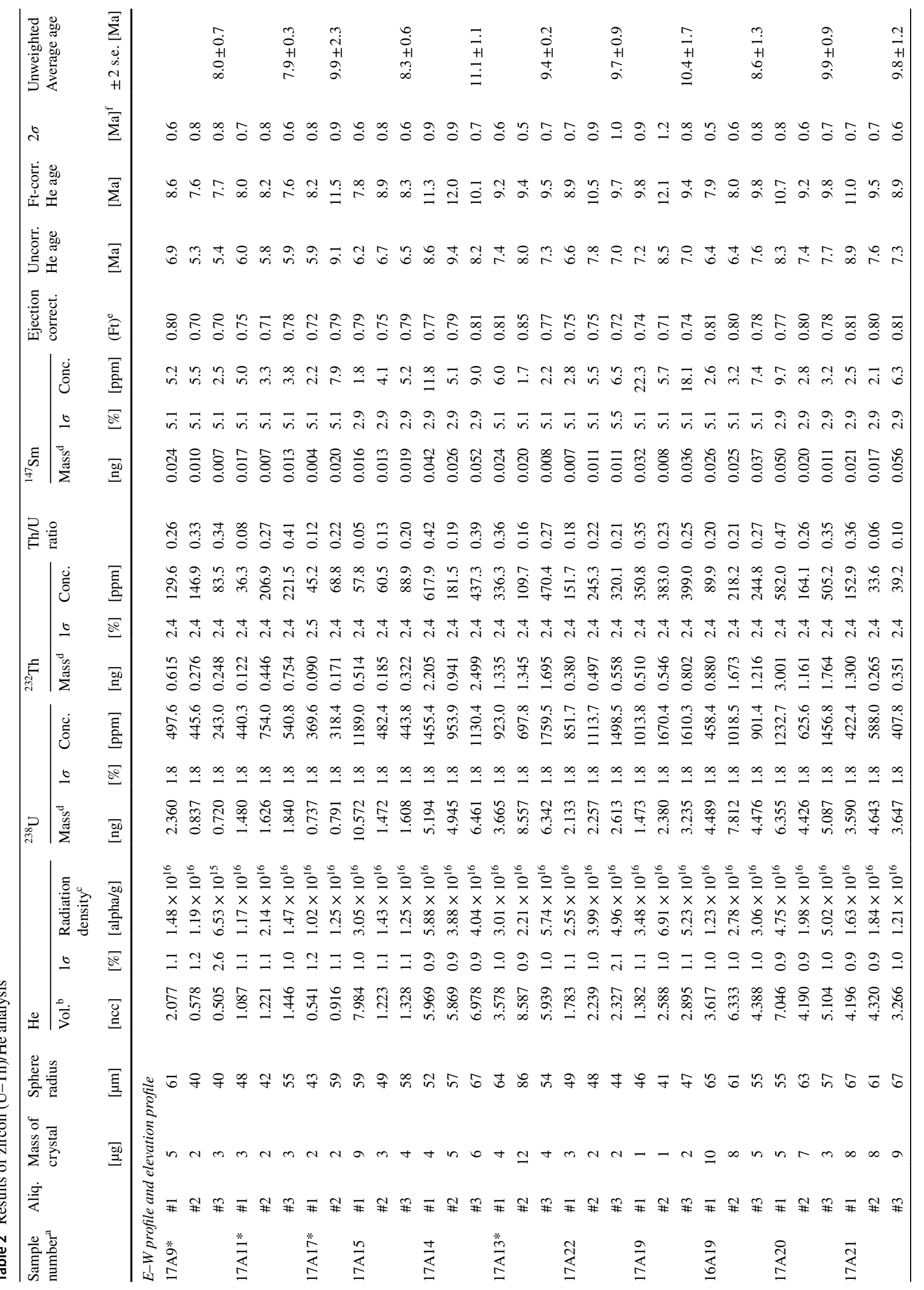




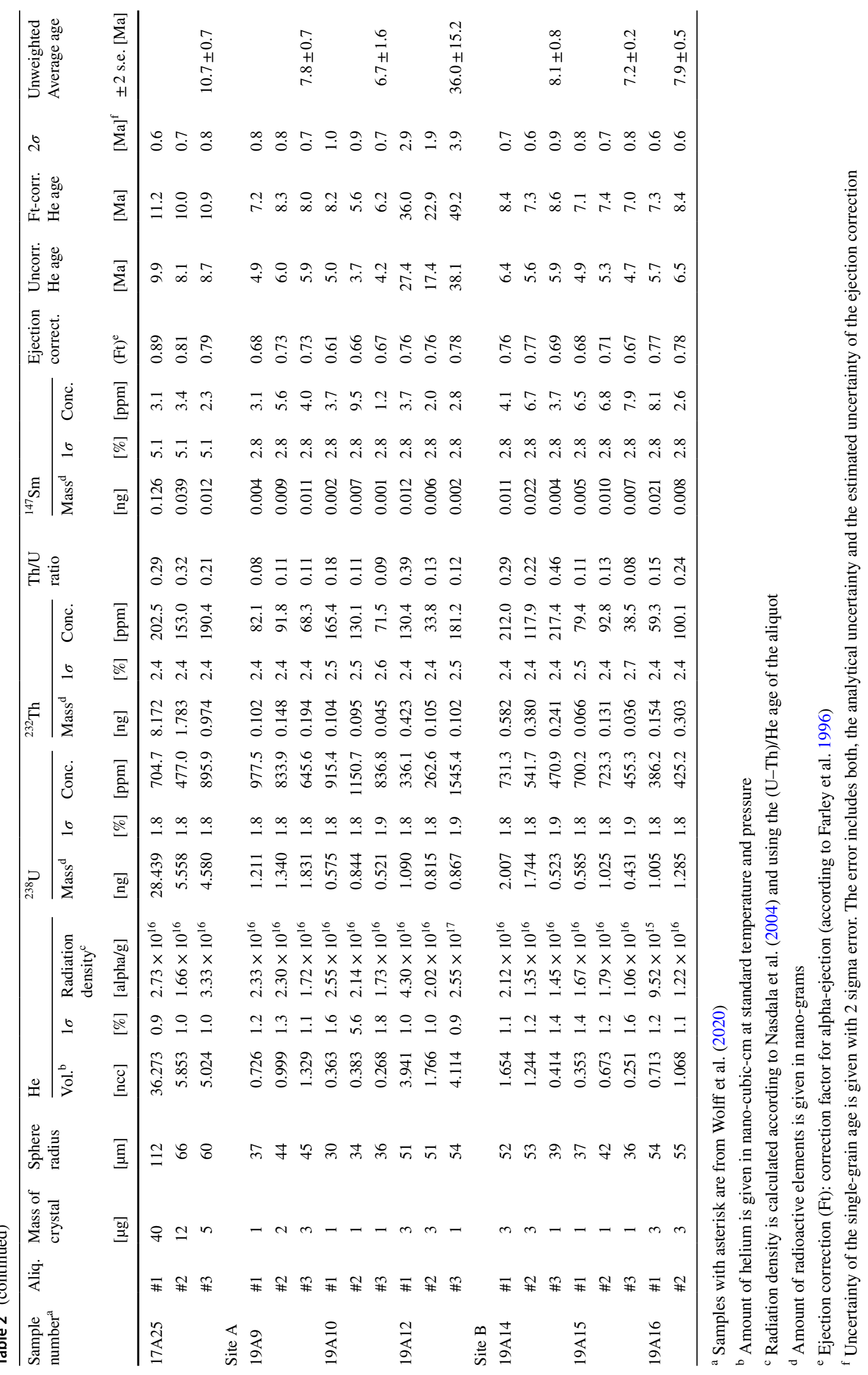




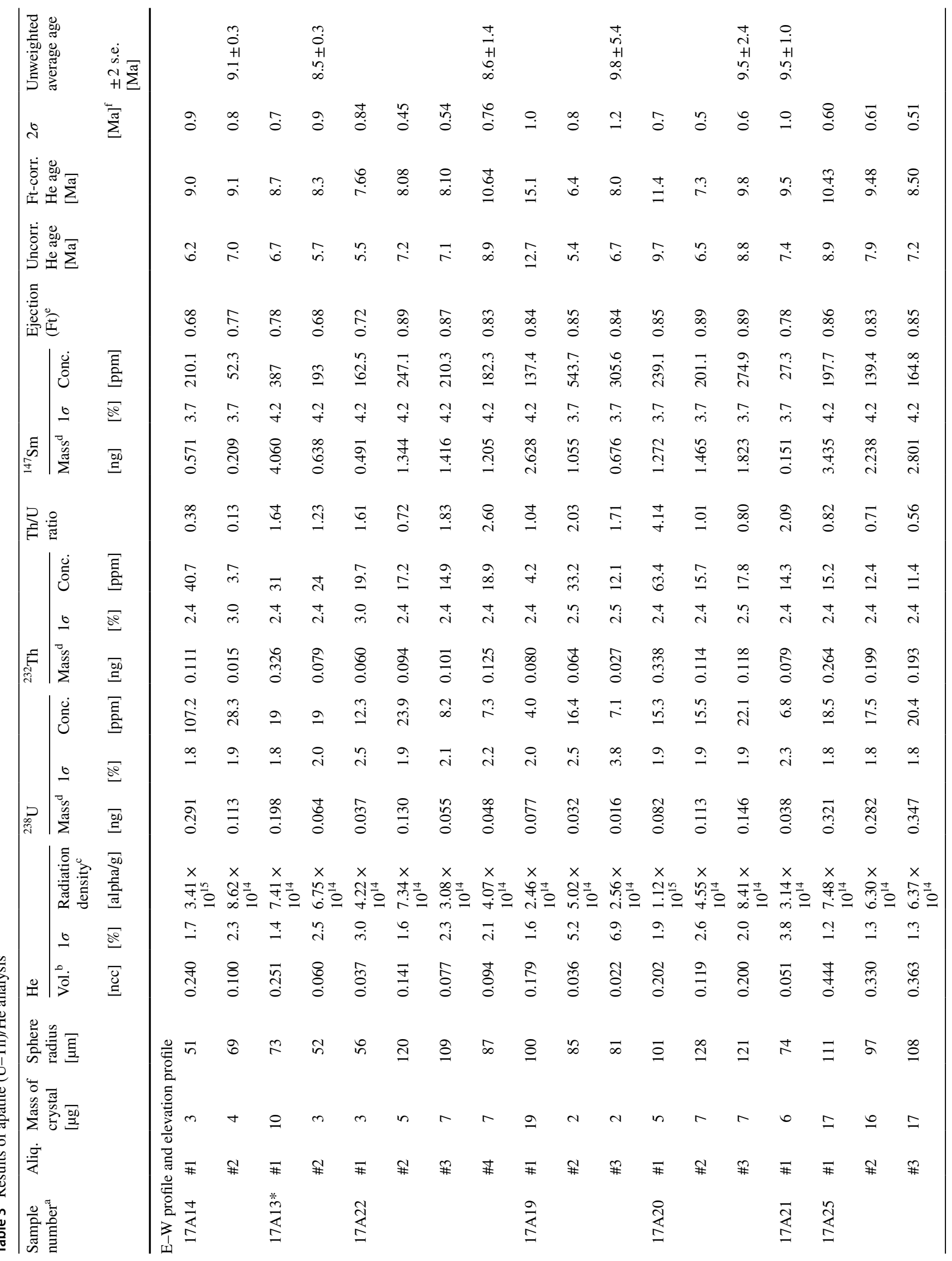




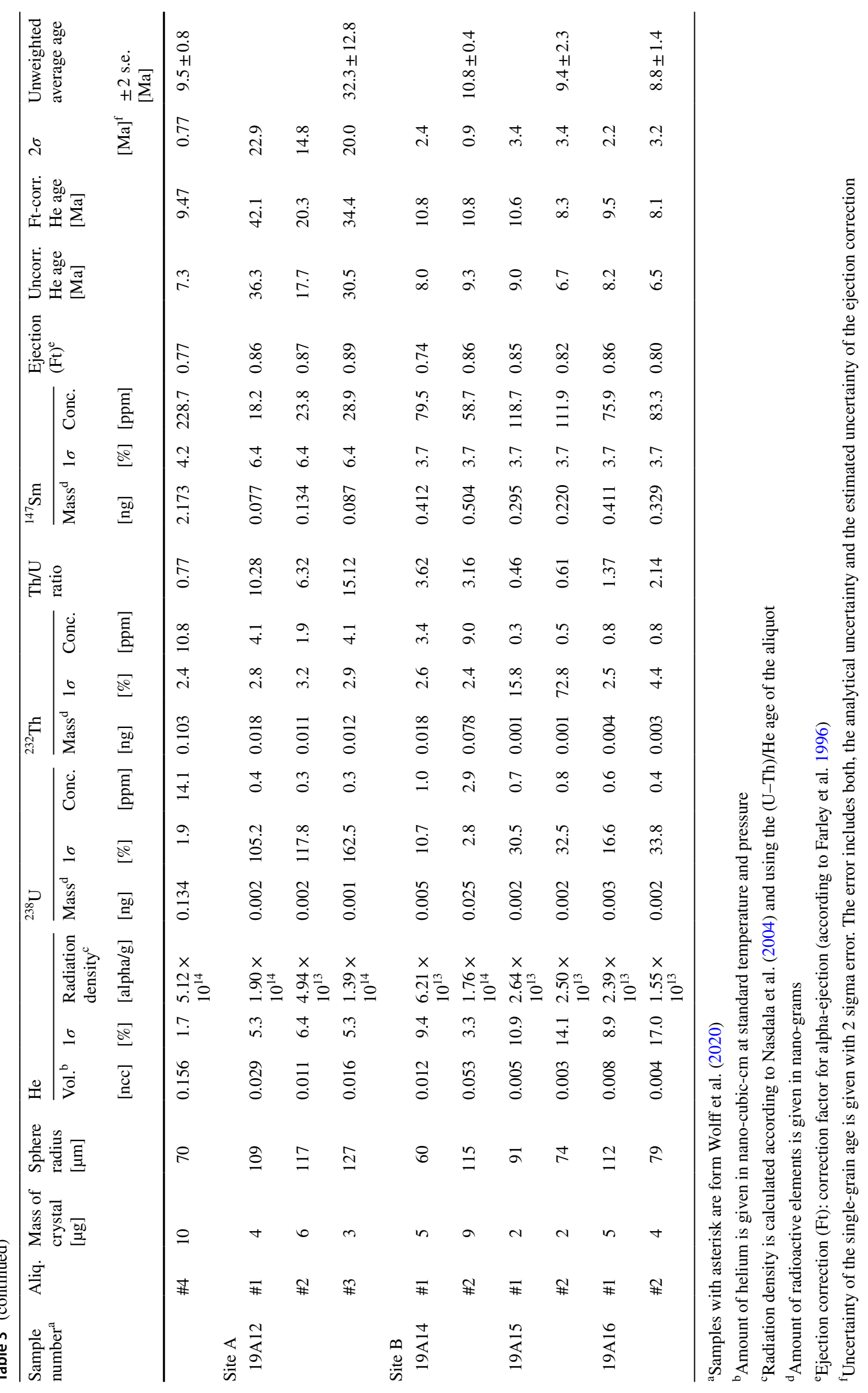


Table 4 Results of apatite fission-track analysis

\begin{tabular}{|c|c|c|c|c|c|c|c|c|c|c|c|c|c|}
\hline \multirow[t]{2}{*}{ Sample number ${ }^{a}$} & \multirow[t]{2}{*}{ No. of crystals } & \multicolumn{2}{|c|}{$\begin{array}{l}\text { Spontane- } \\
\text { ous }\end{array}$} & \multicolumn{2}{|c|}{ Induced } & \multicolumn{2}{|c|}{ Dosimeter $^{b}$} & \multirow{2}{*}{$\begin{array}{l}P\left(\chi^{2}\right) \\
{[\%]}\end{array}$} & \multirow{2}{*}{$\begin{array}{l}\text { Central age }^{\mathrm{c}} \\
\pm 1 \sigma[\mathrm{Ma}]\end{array}$} & \multirow{2}{*}{$\begin{array}{l}\mathrm{MTL}^{\mathrm{d}} \\
{[\mu \mathrm{m}]}\end{array}$} & \multirow{2}{*}{$\begin{array}{l}\text { No. of } \\
\text { measured } \\
\text { TL }\end{array}$} & \multirow{2}{*}{$\begin{array}{l}\text { Dpar } \\
{[\mu \mathrm{m}]}\end{array}$} & \multirow{2}{*}{$\begin{array}{l}U \\
{[\mathrm{ppm}]}\end{array}$} \\
\hline & & $\rho$ & $N$ & $\rho$ & $N$ & $\rho$ & $N$ & & & & & & \\
\hline \multicolumn{14}{|c|}{$\mathrm{E}-\mathrm{W}$ profile and elevation profile } \\
\hline $17 \mathrm{~A} 11^{*}$ & 11 & 0.07 & 11 & 2.09 & 339 & 1.29 & 3887 & 100 & $7.3 \pm 2.2$ & $13.2 \pm 0.3$ & 15 & 1.81 & 20 \\
\hline $17 \mathrm{~A} 16^{*}$ & 20 & 0.10 & 31 & 2.03 & 652 & 1.31 & 3928 & 100 & $10.8 \pm 2.0$ & $12.8 \pm 0.2$ & 41 & 1.76 & 19 \\
\hline $17 \mathrm{~A} 13 *$ & 20 & 0.12 & 32 & 2.89 & 789 & 1.26 & 3786 & 100 & $8.9 \pm 1.6$ & $13.0 \pm 0.2$ & 35 & 1.60 & 27 \\
\hline $17 \mathrm{~A} 22$ & 20 & 0.10 & 27 & 2.30 & 631 & 1.28 & 3837 & 100 & $9.5 \pm 1.9$ & $12.2 \pm 0.3$ & 23 & 1.73 & 22 \\
\hline 17A19 & 20 & 0.11 & 30 & 2.53 & 675 & 1.24 & 3719 & 100 & $9.6 \pm 1.8$ & $12.1 \pm 0.3$ & 11 & 1.62 & 25 \\
\hline 16A19 & 20 & 0.09 & 27 & 2.41 & 754 & 1.32 & 3959 & 100 & $8.2 \pm 1.6$ & $12.6 \pm 0.2$ & 34 & 1.73 & 23 \\
\hline $17 \mathrm{~A} 25$ & 20 & 0.10 & 52 & 2.31 & 1146 & 1.24 & 3711 & 100 & $9.8 \pm 1.4$ & $13.1 \pm 0.3$ & 24 & 1.66 & 23 \\
\hline
\end{tabular}

$\rho$ : track densities are as measured $\left(\times 10^{6} \mathrm{tr} / \mathrm{cm}^{2}\right)$

$N$ : number of tracks counted

$\chi^{2} P[\%]$ : probability obtaining Chi-square value for $n$ degree of freedom ( $n=$ number of crystals -1$)$

$\zeta$ value is $348.2 \pm 6.5 \mathrm{yr} / \mathrm{cm}^{2}$

${ }^{\text {a }}$ Samples with asterisk are from Wolff et al. (2020)

${ }^{\mathrm{b}}$ Using dosimeter glass CN5

${ }^{\mathrm{c}}$ Central age calculated according to Galbraith and Laslett (1993)

${ }^{\mathrm{d}}$ MTL: mean track length (TL)

enable the tracking of all samples during normal faulting and footwall exhumation (Fig. 6). The model parameters used in PECUBE are given in Table 5. The timing of faulting (from 19.0 until $8.8 \mathrm{Ma})$ and the fault-slip rate $(4.2 \mathrm{~km} / \mathrm{Myr})$ were taken from the best-fit model of Wolff et al. (2020).

The cooling ages predicted by our thermokinematic model are shown as red dots in Figs. 7 and 8. It can be seen that our model roughly predicts the $\mathrm{ZHe}$ ages on the long profile (Fig. 7B), although the measured ZHe ages for the two westernmost samples are $\sim 1.5 \mathrm{Ma}$ lower than the modelled ones. The three closely spaced samples at a distance of $\sim 6 \mathrm{~km}$ from the Brenner fault yielded two $\mathrm{ZHe}$ ages that are younger than predicted by the model $(\sim 8.3$ and $\sim 9.4 \mathrm{Ma})$, whereas the third age is older $(\sim 11.1 \mathrm{Ma})$. Despite this variability, the mean of the three $\mathrm{ZHe}$ ages (i.e., 9.6 $\pm 0.8 \mathrm{Ma}$ ) is in good agreement with the modelled ages of $\sim 9.9 \mathrm{Ma}$. The nearly invariant $\mathrm{ZHe}$ ages calculated by our model result from the fact that the $200{ }^{\circ} \mathrm{C}$ isotherm in the model is nearly horizontal at a distance of greater than $\sim 5 \mathrm{~km}$ away from the surface trace of the fault (Fig. 6B) and that the rate of rock exhumation during faulting in the footwall is everywhere the same. In nature, the amount and rate of exhumation commonly decrease away from normal faults over a distance of $20-30 \mathrm{~km}$, because of syntectonic footwall tilting. To take this effect into account, we introduced a kink in the fault plane, which changes its dip from $35^{\circ}$ to $20^{\circ}$ at a distance of $5 \mathrm{~km}$ from of the surface trace of the fault. As the footwall in the model must move parallel to the fault plane, this kink causes footwall tilting and changes the modelled exhumation paths of the samples (cf. Braun et al. 2012; Campani et al. 2010; Styron et al. 2013). As a result, the $\mathrm{ZHe}$ ages predicted by this second model become older with increasing distance from the fault (green dots in Fig. 7). Both models predict the measured ages from all three thermochronometers reasonably well (for reasons outlined in the discussion, we prefer the model without footwall tilting). At the elevation profile near Olperer mountain, the predicted $\mathrm{ZHe}, \mathrm{AFT}$, and AHe of the two models are also in good agreement with the measured cooling ages, except for three previously published AFT ages (Fig. 8).

\section{Sites $A$ and $B$ near Brenner fault}

The westernmost sample at site A (19A12) yields ZHe and AHe ages of $36 \pm 15$ and $32 \pm 13 \mathrm{Ma}$, respectively, whereas the $\mathrm{ZHe}$ ages of the mylonite samples are $6.7 \pm 1.6 \mathrm{Ma}$ and $7.8 \pm 0.7 \mathrm{Ma}$ (Fig. 9, Table 2). Hence, the Brenner normal fault causes an abrupt jump from young ages in the footwall to much older ages in the hanging wall. The age data also demonstrate that the Brenner fault is indeed located on the western shoulder of the valley (Fig. 9).

At site $\mathrm{B}$, the three $\mathrm{ZHe}$ ages range from $7.2 \pm 0.2$ to $8.1 \pm 0.8 \mathrm{Ma}$ and are similar to the $\mathrm{ZHe}$ age of $8.0 \pm 0.7 \mathrm{Ma}$ for the westernmost sample 17A9 on the long profile (Fig. 9). Hence, the main Brenner fault must be located west of the samples and the minor normal fault east of the samples has no significant effect on their cooling history. The AHe ages for the three samples range from $8.8 \pm 1.4$ to $10.8 \pm 0.4 \mathrm{Ma}$, with all nominal ages being higher than the respective $\mathrm{ZHe}$ ages (possible reasons are discussed in Sect. 7.2). 

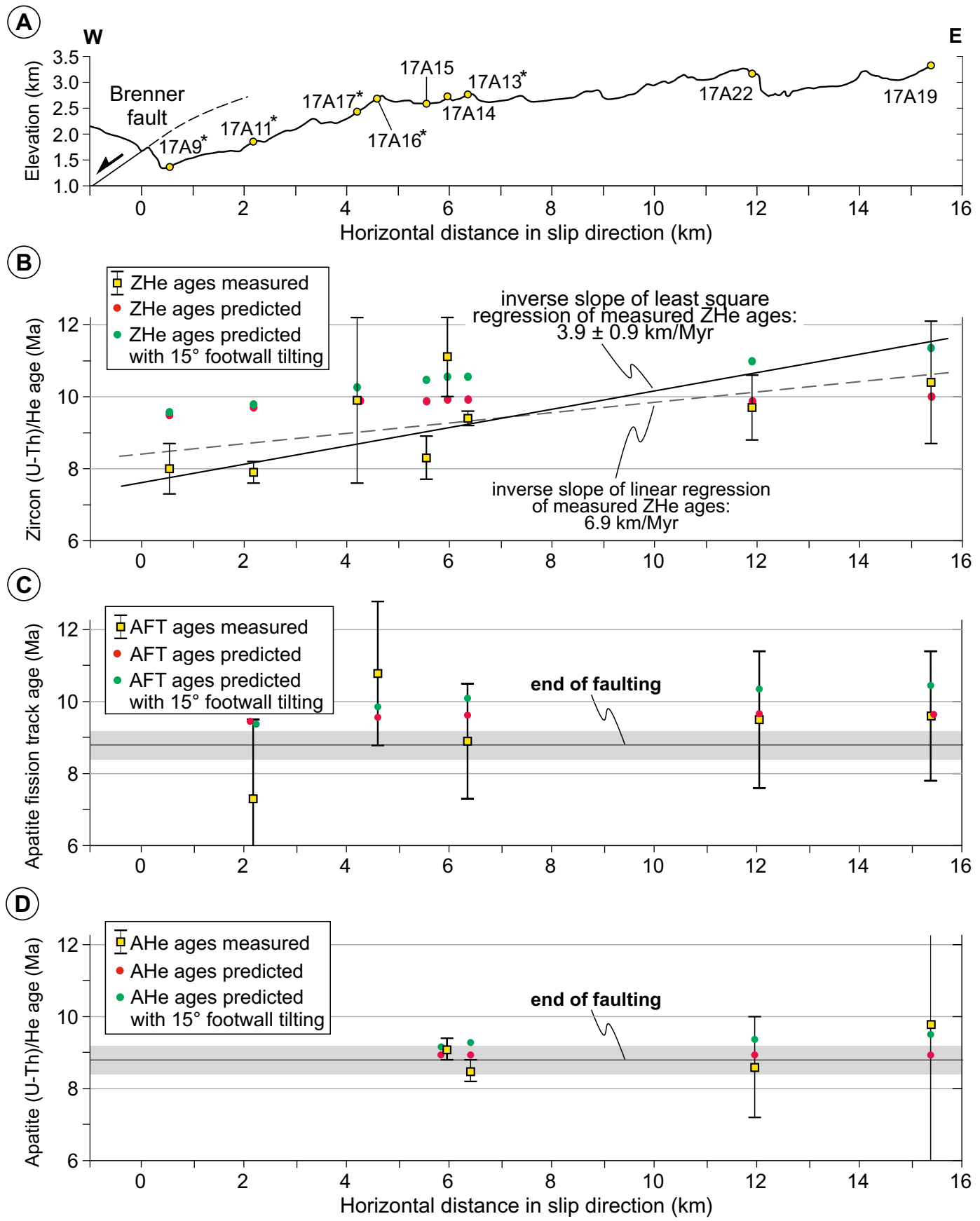

Fig. 7 Thermochronological samples and age data along profile located in the footwall of the Brenner normal fault. Samples are projected on E-W profile parallel to the fault-slip direction. A Topographic profile with samples shown as yellow circles. B-D ZHe, $\mathrm{AFT}$, and AHe ages with uncertainties along profile shown in (A).

\section{Discussion}

\section{Interpretation of thermochronological ages in fault footwall}

The ZHe ages predicted by our thermokinematic models (with and without footwall tilting) are broadly in agreement
Red and green dots indicate the ages predicted by the thermokinematic models described in Sect. 6.2. The horizontal grey line in $\mathbf{C}$ and $\mathbf{D}$ indicates the end of normal faulting on the Brenner fault at $8.8 \pm 0.4 \mathrm{Ma}$ (Wolff et al. 2020)

with those measured along the profile in the footwall of the Brenner normal fault (Fig. 7B). As the misfit $\phi$ between our $\mathrm{ZHe}$ ages and the ages predicted by the two models is smaller for the model without footwall tilting (misfit $\phi$ of 1.9 versus $\phi$ of 2.6; calculated after Braun et al. 2012), we prefer this model over the one with footwall tilting. A regression line through the $\mathrm{ZHe}$ ages yields an inverse slope of 

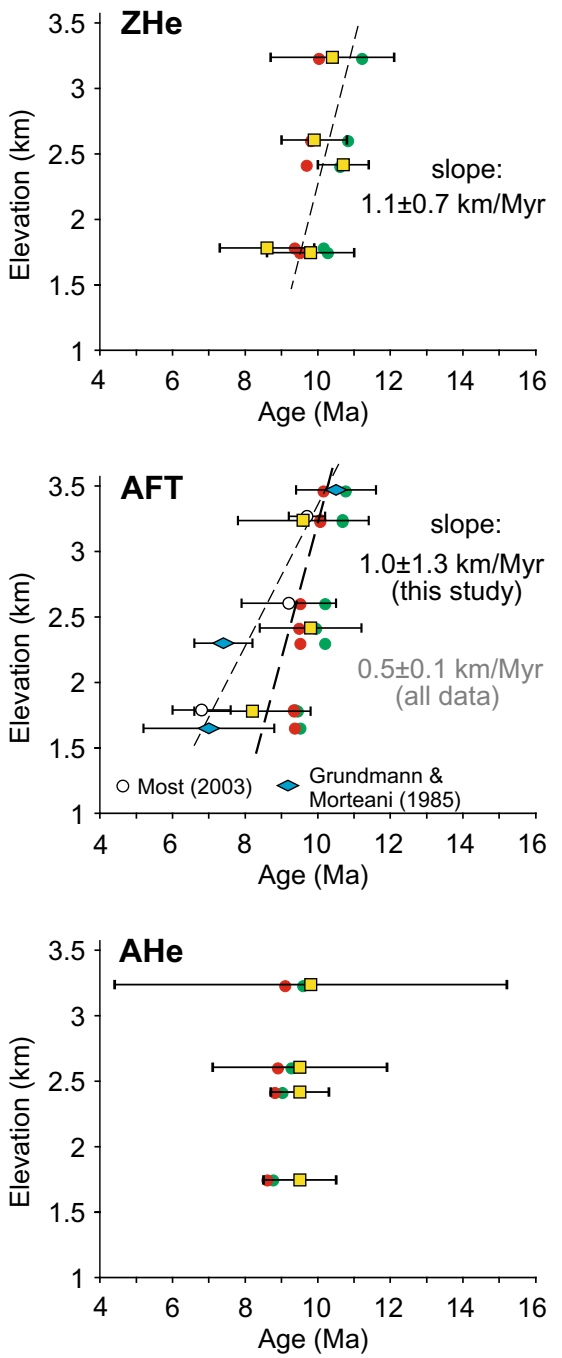

$\mapsto$ Ages from this study

- Ages predicted by PECUBE model

- Ages predicted by PECUBE model with footwall tilted by $15^{\circ}$

Fig. $8 \mathrm{ZHe}$, AFT, and AHe ages with uncertainties for samples of the elevation profile near Olperer mountain. Red and green dots indicate the ages predicted by the thermokinematic models described in Sect. 6.2. Regression lines obtained by least-square fit through the data are shown for the $\mathrm{ZHe}$ and the AFT ages

$6.9 \mathrm{~km} / \mathrm{Myr}$ (dashed line in Fig. 7B). Without caution, this value could be interpreted as the fault-slip rate during crustal extension; however, the following reasons argue against such a simple interpretation. First, there is considerable scatter in the age data and the uncertainties of the individual $\mathrm{ZHe}$ ages are quite variable. Second, a least-square fit, which takes these different uncertainties into account, gives an inverse slope of only $3.9 \pm 0.9 \mathrm{~km} / \mathrm{Myr}$. This lower value agrees with the fault-slip rate of $4.2 \pm 0.9 \mathrm{~km} / \mathrm{Myr}$ obtained from a PECUBE model that accurately predicts the ZHe, AFT, and AHe ages from a $2-\mathrm{km}$-long elevation profile near the
Table 5 Parameters of PECUBE model for Brenner fault

\begin{tabular}{ll}
$\begin{array}{l}\text { Model dimensions: length, width, } \\
\text { depth }\end{array}$ & $55 \mathrm{~km}, 20 \mathrm{~km}, 70 \mathrm{~km}$ \\
$\begin{array}{l}\text { Temperature at base of model } \\
\text { Temperature at top of model }\end{array}$ & $800^{\circ} \mathrm{C}$ \\
Radiogenic heat production & $5^{\circ} \mathrm{C}$ \\
E-folding depth of heat production & $2.6 \times 10^{-6} \mathrm{~W} / \mathrm{m}^{3}\left(=30^{\circ} \mathrm{C} / \mathrm{Myr}\right)$ \\
Thermal diffusivity & $6.4 \times 10^{-7} \mathrm{~m}^{2} / \mathrm{s}\left(=20 \mathrm{~km}^{2} / \mathrm{Myr}\right)$ \\
Crustal density & $2700 \mathrm{~kg} / \mathrm{m}^{3}$ \\
Mantle density & $3200 \mathrm{~kg} / \mathrm{m}^{3}$ \\
Fault dip & $35^{\circ}$ \\
\hline
\end{tabular}

The values given in parentheses are the units used by PECUBE

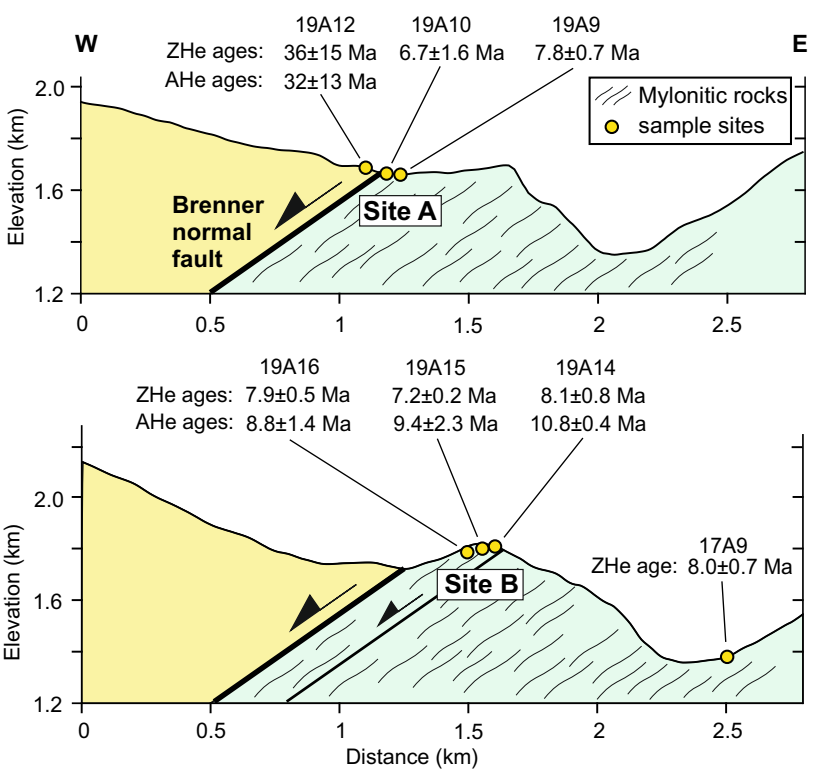

Fig. 9 Topographic profiles with $\mathrm{ZHe}$ and $\mathrm{AHe}$ ages at sites $\mathrm{A}$ and B. For location, see Fig. 3b and Fig. 5. The footwall and the hanging wall of the Brenner fault are shown in different colors

Brenner fault (Wolff et al. 2020). According to this model, the Brenner fault was active for $\sim 10 \mathrm{Ma}$ (i.e., from $19 \pm 2$ to $8.8 \pm 0.4 \mathrm{Ma}$ ) and caused $35 \pm 10 \mathrm{~km}$ of crustal extension. If we would use the inverse slope value of $6.9 \mathrm{~km} / \mathrm{Myr}$ and a faulting period of $10 \mathrm{Ma}$, this would imply a much higher amount of extension of $\sim 70 \mathrm{~km}$. Although such a high value was initially proposed for the Brenner fault (Fügenschuh et al. 1997), it was later revised to a value of $\sim 44 \mathrm{~km}$ (Fügenschuh et al. 2012), which is compatible with our data and preferred model. Therefore, we argue that our new $\mathrm{ZHe}$ data and our enlarged PECUBE model confirm the results of Wolff et al. (2020). Finally, we note that both the AFT and the AHe ages show no correlation with distance to the Brenner fault (Fig. 7C, D) and can therefore not be used to derive a fault-slip rate. At least for the AHe ages, we interpret this lack of correlation to result from the rapid cooling of the 
fault footwall by the combined effects of normal faulting and the subsequent thermal relaxation (Fig. 6B). For the AFT ages, a trend in the ages with distance to the fault may be obscured by the relatively large errors of the ages.

The ZHe, AFT, and AHe ages of the elevation profile are also rather well reproduced by our two thermokinematic models (Fig. 8). Again, the misfit $\phi$ between the measured and predicted thermochronological ages is smaller for the model without footwall tilting ( $\phi$ of 1.2 versus $\phi$ of 1.4). The inverse slopes obtained by least-square regressions through the ZHe and AFT age data are $1.1 \pm 0.7$ and $1.0 \pm 1.3 \mathrm{~km} /$ Myr, respectively (Fig. 8). These values could be interpreted as exhumation rates during normal faulting, provided that the isotherms in the upper crust were spatially and temporally invariant during the period of cooling recorded by the data. As the vertical slip rate of the Brenner fault derived from our thermokinematic model is $2.4 \pm 0.4 \mathrm{~km} / \mathrm{Myr}$, the nominal slope values underestimate the modelled exhumation rate. Whatever may be the reasons for this discrepancy, the relatively large uncertainties of the slope values imply that they are still roughly consistent with our model.

The nominal AHe ages on the elevation profile are nearly invariant (Fig. 8) and the same is true for the upper part of the age-elevation profile near the Brenner fault studied by Wolff et al. (2020); for location, see Fig. 5. Here, the nearly identical AHe ages were interpreted to be caused by rapid tectonic exhumation followed by thermal relaxation after the end of normal faulting (Wolff et al. 2020). The similarity between both elevation profiles and the observation that the AHe ages along the WSW-ENE profile are also invariant (see Fig. 7D), indicates that the processes of heat advection during normal faulting and the subsequent thermal relaxation after faulting are reflected in our entire age data set (i.e., up to a distance of at least $16 \mathrm{~km}$ from the Brenner fault).

\section{Interpretation of thermochronological data at sites $A$ and $B$}

At site A, there is a significant age difference between our two $\mathrm{ZHe}$ ages in the footwall ( 7 and $\sim 8 \mathrm{Ma})$ and the $\mathrm{ZHe}$ age of $36 \pm 15 \mathrm{Ma}$ in the hanging wall of the Brenner fault (Fig. 9). The ZHe ages for three samples at distances of 0.5-3 km west of the Brenner fault (Fig. 5) range from $63 \pm 7$ to $71 \pm 10 \mathrm{Ma}$ and show no spatial trend (Lünsdorf et al. 2012). We interpret the overall age pattern to be caused by a local heating of the fault hanging wall during its emplacement against the hot footwall. This heating has affected only our sample with the ZHe age of $\sim 36 \mathrm{Ma}(\sim 100 \mathrm{~m}$ away from the fault), but not the three samples of Lünsdorf et al. (2012).

At site B, the nominal AHe ages of the three mylonitic samples in the fault footwall are slightly older than their $\mathrm{ZHe}$ ages, with the oldest AHe age being 10.8 $\pm 0.4 \mathrm{Ma}$ (Fig. 9). Processes that may cause such elevated AHe ages include the incorporation of excess $\mathrm{He}$ from hydrothermal fluids (e.g., Zeitler et al. 2017), in particular in or near fault zones (e.g., Wölfler et al. 2010; Louis et al. 2019; Milesi et al. 2019), and the mobilization of $U$ from apatite by acidic fluids (e.g., Milesi et al. 2019). In this context, it is important to note that the $U$ concentration of apatite in the Bündner schists of the Matrei zone is rather low. The apatites analyzed at site B have U concentrations of $0.4-2.9 \mathrm{ppm}$, significantly lower than those of apatite in the coarse-grained orthogneiss samples discussed above, which range from 4 to $107 \mathrm{ppm}$ (Table 3). Owing to the low $\mathrm{U}$ content of apatite and the small grain size of the Bündner schists, the rocks near the Brenner fault are likely susceptible to fluid flow, hydrothermal alteration, and a change of their (U-Th)/He systematics either during or after faulting. Therefore, the elevated AHe ages at site B should not be interpreted as geologically meaningful cooling ages.

\section{Effect of enhanced footwall cooling near the Brenner fault}

During normal faulting and heat advection, isotherms in the fault footwall are shifted towards the surface and the conduction of heat into the hanging wall leads to a warping of the isotherms (Grasemann and Mancktelow 1993; Ketcham 1996; Seward et al. 2009). When faulting stops, the upper crust in the fault footwall cools rapidly during thermal relaxation (Braun 2016). To illustrate these processes, we use the thermokinematic model without footwall tilting described in Sect. 6.2 and the faulting history of the Brenner fault (Wolff et al. 2020). The thermal structure in this model is shown at four different time steps (Fig. 10A). Due to the warping of the isotherms, the cooling ages predicted for different thermochronometers in the fault footwall increase towards the fault over a distance of up to $30 \mathrm{~km}$ (Fig. 10B). It is important to note that the increase in cooling ages is larger for systems with higher closure temperature and smaller for low-temperature thermochronometers. Hence, for low-temperature systems such as AHe and AFT, the effect may not be detectable. However, for geochronological systems with higher closure temperature, this effect is recognizable and needs to be considered as illustrated by $\mathrm{K}-\mathrm{Ar}$ phengite and biotite ages from two sites located $\sim 6$ and $\sim 13 \mathrm{~km}$ east of the Brenner fault (i.e., Landshuter Hütte and Pfitscher-Joch; for location see Fig. 5). The mean $\mathrm{K}-\mathrm{Ar}$ ages for phengite $(15.6 \pm 2.0$ and $14.5 \pm 1.1 \mathrm{Ma})$ and biotite $(13.8 \pm 0.8$ and $12.9 \pm 0.2 \mathrm{Ma}$ ) at these two sites (von Blanckenburg et al. 1989) are in good agreement with our model predictions (Fig. 10B). The position of the two sites during and after faulting is shown in Fig. 10A. The K-Ar ages for phengite and biotite predicted by our model correspond to closure temperatures of 450 and $400{ }^{\circ} \mathrm{C}$, respectively, and fall in the 

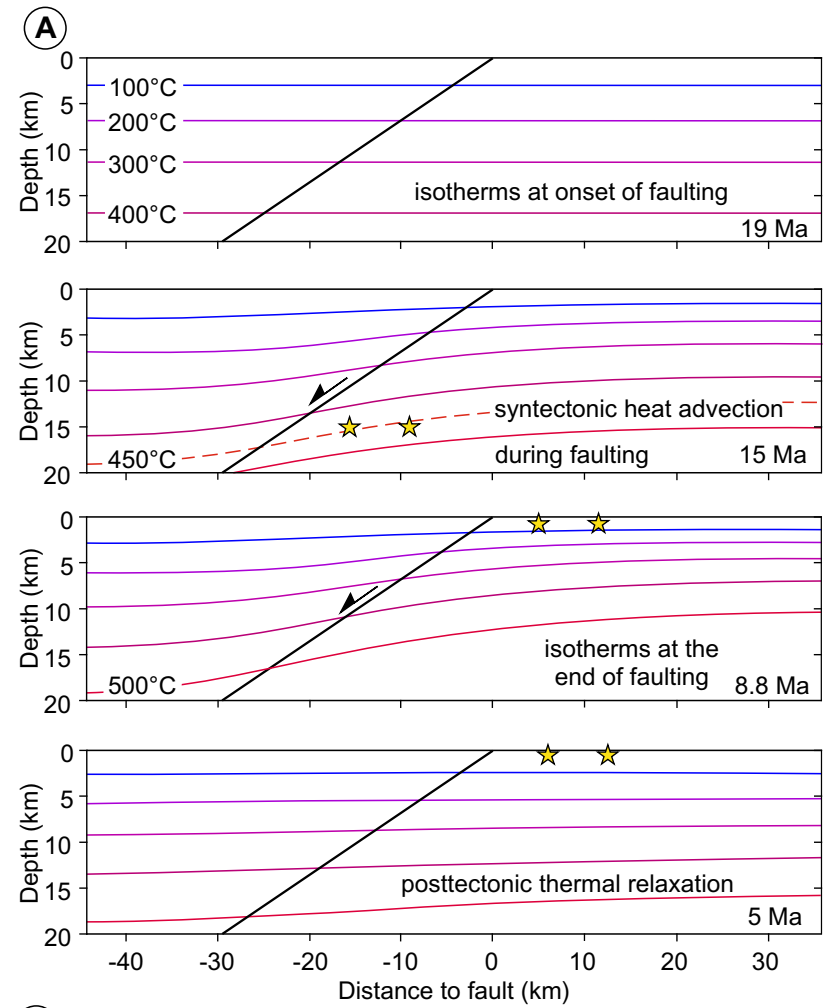

(B)

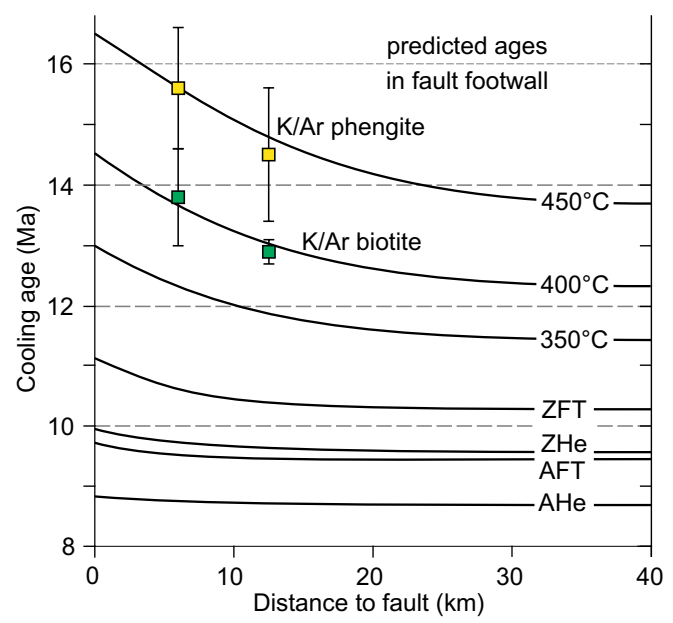

Fig. 10 A Results of thermokinematic model illustrating how heat advection during normal faulting (from 19 to $8.8 \mathrm{Ma}$ ) shifts the isotherms in the fault footwall towards the surface. As a result of warping of the isotherms, cooling ages in the fault footwall increase towards the fault. When faulting stops, the upper crust cools rapidly during thermal relaxation (compare the two model stages at 8.8 and $5 \mathrm{Ma}$ ). The model used to generate this figure is identical to that described in Sect. 6.2, except that the model surface is horizontal. B Predicted cooling ages in the fault footwall increase towards the normal fault. Note that the effect is minor for low-temperature thermochronometers (AHe, AFT, and $\mathrm{ZHe}$ ) but becomes more pronounced for thermochronometers with higher closure temperature. The phengite and biotite $\mathrm{K}-\mathrm{Ar}$ ages of samples from Landshuter Hütte and Pfitscher-Joch Haus (see Fig. 5 for location) are from von Blanckenburg et al. (1989). The position of these samples is shown in (A) by yellow stars at $15,8.8$, and $5 \mathrm{Ma}$ range of closure temperatures previously inferred for these systems (e.g., Villa 1998; Chew and Spikings 2015).

Phengite $\mathrm{Rb}-\mathrm{Sr}$ ages in the westernmost Tauern Window are more variable (i.e., $20.3 \pm 0.3$ to $15.6 \pm 0.4 \mathrm{Ma}$ ), but they do not increase towards the Brenner fault (von Blanckenburg et al. 1989). This observation can be explained by our finding that the Brenner fault became active $19 \pm 2 \mathrm{Ma}$ ago. At this time, the warping of the isotherms as a result of normal faulting was just about to start. Therefore, a significant cooling of the footwall of the Brenner fault has not yet occurred when the samples cooled through the closure temperature of $\mathrm{Rb}-\mathrm{Sr}$ in phengite.

\section{Folding and erosion as a mechanism for the exhumation of the Tauern Window}

On N-S profiles through the Tauern Window, cooling ages from different thermochronological systems (AFT, ZFT, $\mathrm{K}-\mathrm{Ar}$ mica, $\mathrm{U}-\mathrm{Pb}$ apatite) form a U-shaped pattern, with ages increasing towards the north and south. Based on predictions by two-dimensional thermomechanical models for compressional orogens (Batt and Braun 1997), this spatial distribution of cooling ages has been interpreted to reflect $\mathrm{N}-\mathrm{S}$ shortening, folding, and coeval erosion (Rosenberg and Garcia 2011; Schneider et al. 2015; Bertrand et al. 2017; Rosenberg et al. 2018). Although this interpretation is able to explain the available age data in the central part of the Tauern Window, the effect of the Brenner normal fault on the cooling and exhumation history of the westernmost $20-30 \mathrm{~km}$ of the window is not adequately accounted for in this interpretation for the following reasons. First, the age difference between ZFT and AFT ages along an $\sim \mathrm{E}-\mathrm{W}$ profile through the Tauern Window decreases markedly in its western part (Bertrand et al. 2017, their Fig. 10), which suggests an increase in the rates of cooling and exhumation towards the west. We interpret this pattern to reflect the combined effect of heat advection and thermal relaxation during and after normal faulting on the Brenner fault. A similar pattern of ZFT and AFT ages is seen in the eastern Tauern Window and seems to be caused by the Katschberg normal fault (cf. Genser and Neubauer 1988; Scharf et al. 2013), although this interpretation remains to be evaluated by thermokinematic modeling. Second, the westward increase in $\mathrm{K}-\mathrm{Ar}$ phengite and biotite ages towards the Brenner fault (Fig. 10) is caused by cooling of the footwall during normal faulting (see Sect. 7.3) and cannot be explained by folding around $\mathrm{E}-\mathrm{W}$ trending axes and erosion. Third, the $\mathrm{E}-\mathrm{W}$ gradient in $\mathrm{ZHe}$ cooling ages (Fig. 7b) reflects the progressive exhumation of the western Tauern Window by normal faulting, whereas the largely invariant AHe and AFT ages on the vertical transect at Olperer mountain (Fig. 8) are best explained by heat advection during normal faulting and exhumation followed by posttectonic thermal relaxation 
(Fig. 6) (cf. Wolff et al. 2020). Finally, we note that erosion can only have affected the rocks of the western Tauern Window once they were tectonically exhumed from beneath the hanging wall by slip on the Brenner fault. As long as the rocks were buried below the fault hanging wall (i.e., Steinach nappe and Ötztal nappe with its sedimentary cover; Figs. 2 and 5), erosion can only have affected units in the hanging wall. However, these units experienced only a limited amount of erosion during the past $\sim 20 \mathrm{Ma}$ as shown by AFT, ZHe, and ZFT ages that are much older than those in the western Tauern Window (Fügenschuh et al. 1997, 2012; Lünsdorf et al. 2012; Wolff et al. 2020).

\section{Amount and rate of valley incision after cessation of normal faulting}

After normal faulting on the Brenner fault had ceased, an $\mathrm{N}-\mathrm{S}$ trending valley has been incised into the fault footwall. The location of this valley was presumably controlled by differences in rock strength between the resistant hanging wall units (Steinach nappe and Brenner Mesozoic) and weaker rocks in the fault footwall (Matrei zone, Glockner, and Modereck nappes) (Fig. 3). The maximum estimates for the amount of valley incision (750-1200 $\mathrm{m}$ on profiles P1-P5) are based on a fault dip of $35^{\circ}$ (broadly consistent with our field observations; Fig. 4). With respect to the fault dip, we note that Rosenberg and Garcia (2011) estimated quite variable fault dips of $19^{\circ}-57^{\circ}$ between Sterzing and Gries am Brenner (for location of these towns, see Figs. 2 and 3). Based on our topographic profiles, we suggest that a value of $1000 \mathrm{~m}$ is a reasonable average for the amount of incision and assign an uncertainty of $\pm 300 \mathrm{~m}$ to this value. If we combine this estimate $(1000 \pm 300 \mathrm{~m})$ with the time constraint for the end of normal faulting $(8.8 \pm 0.4 \mathrm{Ma}$; Wolff et al. 2020), we obtain a time-averaged incision rate of about $110 \mathrm{~m} / \mathrm{Myr}$ in the Brenner pass area. This incision rate is in agreement with the exhumation rate of $0.1 \mathrm{~km} / \mathrm{Myr}$ after the end of normal faulting derived from the PECUBE model (Wolff et al. 2020). Given that the valley is situated in the internal part of the Alpine mountain chain, this long-term incision rate is surprisingly low. One may argue that erosion and valley incision have accelerated in the Quaternary as a result of frequent climate oscillations and enhanced glacial or fluvial erosion (e.g., Valla et al. 2011; Leith et al. 2018). However, even if we assume that rates of erosion and valley incision increased by a factor of four after $2.5 \mathrm{Ma}$, we obtain a Quaternary incision rate of only $250 \mathrm{~m} / \mathrm{Myr}$, while the pre-Quaternary rate would be $\sim 60 \mathrm{~m} / \mathrm{Myr}$. In this scenario, the Quaternary incision rate is still much lower than rates of erosion and valley deepening inferred in other parts of the Alps. In the central Alps, for example, incision rates of
$1.0-1.5 \mathrm{~km} / \mathrm{Myr}$ have been derived from burial dating of cave sediments (Haeuselmann et al. 2007), ${ }^{4} \mathrm{He} /{ }^{3} \mathrm{He}$ thermochronometry (Valla et al. 2011), and topographic signatures indicative of fluvial incision (Leith et al. 2018). In the high part of the western Alps, exhumation rates of $>1 \mathrm{~km} / \mathrm{Myr}$ over the last $3 \mathrm{Ma}$ were estimated from low-temperature thermochronological data (Glotzbach et al. 2008).

We suggest that the main reasons for the limited amount of valley incision (either by fluvial or glacial processes) in the area of the Brenner pass are the position of the Alpine drainage divide, which runs through the study area (Fig. 3). As the location of the drainage divide coincides with the maximum displacement on the Brenner fault (cf. Rosenberg et al. 2011), the $\mathrm{N}-\mathrm{S}$ trending valley with its low-channel gradient appears to be related to the Brenner normal fault. As glacial erosion rates scale with ice discharge and basal sliding speed, which increase with valley gradient (e.g., Hallet 1979; Anderson et al. 2006), the amount of glacial (and fluvial) erosion during the Quaternary was limited by the low valley gradient near the Brenner drainage divide. This is consistent with a recent ice-flow modeling study, which indicates that the ice-flow divide during the last glaciation of the Alps was located near the current drainage divide and that the ice-surface velocity in the Brenner pass region was below $20 \mathrm{~m} / \mathrm{yr}$ (Seguinot et al. 2018). Our interpretation of a limited amount of erosion $(\sim 1000 \mathrm{~m})$ after the end of normal faulting is consistent with the absence of well-developed U-shaped valleys in the Brenner region.

\section{Conclusions}

Our thermochronological data and thermokinematic modeling show that the Brenner normal fault exerted an important control on the cooling and exhumation history of the rocks exposed in the westernmost $\sim 25 \mathrm{~km}$ of the Tauern Window. Normal faulting caused the advection of hot rocks towards the surface and the conduction of heat into the cooler hanging wall. After faulting ended at $\sim 9 \mathrm{Ma}$, posttectonic thermal relaxation induced rapid cooling of the upper crust, which explains the invariant $\mathrm{AHe}$ ages on horizontal and vertical profiles. Farther to the east, the effect of the Brenner normal fault seems to vanish and the exhumation of the metamorphic rocks in the Tauern Window may have largely been controlled by prolonged $\mathrm{N}-\mathrm{S}$ shortening, folding, and erosion (e.g., Rosenberg et al. 2018). The topography of the Brenner area-where the Brenner normal fault runs along the western shoulder of a $\mathrm{N}-\mathrm{S}$ valley, which was incised into the fault footwall after faulting ceased-indicates that fluvioglacial erosion and valley incision near the drainage divide of the Alps were limited to about $1 \mathrm{~km}$ in the past $\sim 9 \mathrm{Ma}$. 
Acknowledgements We thank Martin Danišík and an anonymous reviewer for their helpful comments, which improved the presentation and interpretation of the data contained in this paper. We are grateful to R. Jacoby for help during the field campaign and J. Dunklné Nagy for help in the laboratory. The digital elevation model used in Figs. 3 and 5 is based on TanDEM-X data from the German Aerospace Centre (DLR).

Funding Open Access funding enabled and organized by Projekt DEAL. We acknowledge funding for field work and sample analysis by the University of Münster.

Data availability The code PECUBE by J. Braun used in this work is available at https://github.com/jeanbraun. The thermochronological data of this study are contained in Tables 2, 3, and 4.

\section{Declarations}

Conflict of interest The authors declare that they have no conflict of interests.

Open Access This article is licensed under a Creative Commons Attribution 4.0 International License, which permits use, sharing, adaptation, distribution and reproduction in any medium or format, as long as you give appropriate credit to the original author(s) and the source, provide a link to the Creative Commons licence, and indicate if changes were made. The images or other third party material in this article are included in the article's Creative Commons licence, unless indicated otherwise in a credit line to the material. If material is not included in the article's Creative Commons licence and your intended use is not permitted by statutory regulation or exceeds the permitted use, you will need to obtain permission directly from the copyright holder. To view a copy of this licence, visit http://creativecommons.org/licenses/by/4.0/.

\section{References}

Anderson R, Molnar P, Kessler MA (2006) Features of glacial valleys profiles simply explained. J Geophys Res 111:F01004. https:// doi.org/10.1029/2005JF000344

Ault AK, Selverstone J (2008) Microtextural constraints on the interplay between fluid-rock reactions and deformation. Contrib Miner Petrol 156:501-515

Batt GE, Braun J (1997) On the thermomechanical evolution of compressional orogens. Geophys J Int 128:364-382

Behrmann JH (1988) Crustal-scale extension in a convergent orogen. The Sterzing-Steinach mylonite zone in the Eastern Alps. Geodin Acta 2:63-73

Behrmann JH, Frisch W (1990) Sinistral ductile shearing associated with metamorphic decompression in the Tauern Window, Eastern Alps. Jb Geol BA Wien 133:135-146

Bertrand A, Rosenberg C, Rabaute A, Herman F, Fügenschuh B (2017) Exhumation mechanisms of the Tauern Window (Eastern Alps) inferred from apatite and zircon fission track thermochronology. Tectonics 36:207-228

Bögel H (1975) Zur Literatur über die "Periadriatische Naht." Verh Geol BA Austria 2-3:163-199

Bousquet R, Oberhänsli R, Goffé B, Wiederkehr M, Koller F, Schmid SM, Schuster R, Engi M, Berger, A, Martinotti G (2008) Metamorphism of metasediments at the scale of an orogen: a key to the Tertiary geodynamic evolution of the Alps. Geol Soc London Spec Publ 298:393-411
Brady RJ (2002) Very high slip rates on continental extensional faults. New evidence from (U-Th)/He thermochronometry of the Buckskin Mountains. Arizona Earth Planet Sci Lett 197:95-104

Braun J (2016) Strong imprint of past orogenic events on the thermochronological record. Tectonophysics 683:325-332

Braun J, van der Beek P, Valla P, Robert X, Herman F, Glotzbach C, Pedersen V, Perry C, Simon-Labric T, Prigent C (2012) Quantifying rates of landscape evolution and tectonic processes by thermochronology and numerical modeling of crustal heat transport using PECUBE. Tectonophysics 524-525:1-28

Brichau S, Thomson S, Ring U (2010) Thermochronometric constraints on the tectonic evolution of the Serifos detachment, Aegean Sea, Greece. Int J Earth Sci 99:379-393

Burtner RL, Nigrini A, Donelick RA (1994) Thermochronology of Lower Cretaceous source rocks in the Idaho-Wyoming thrust belt. Am Assoc Petrol Geol Bull 78:1613-1636

Buscher JT, Hampel A, Hetzel R, Dunkl I, Glotzbach C, Struffert A, Akal C, Ratz M (2013) Quantifying rates of detachment faulting and erosion in the central Menderes Massif (western Turkey) by thermochronology and cosmogenic ${ }^{10} \mathrm{Be}$. J Geol Soc Lond 170:669-683

Campani M, Herman F, Mancktelow N (2010) Two- and three-dimensional thermal modeling of a low-angle detachment. Exhumation history of the Simplon Fault Zone, central Alps. J Geophys Res 115:B10420

Chew DM, Spikings RA (2015) Geochronology and thermochronology using apatite: time and temperature, lower crust to surface. Elements 11:189-194

Cliff RA, Oberli F, Meier M, Droop GTR, Kelly M (2015) Syn-metamorphic folding in the Tauern Window, Austria dated by Th- $\mathrm{Pb}$ ages from individual allanite porphyroblasts. J Meatamorphic Geol 33:427-435

Dal Piaz GV, Bistacchi A, Massironi M (2003) Geological outline of the Alps. Episodes 6:175-180

Donelick RA, Ketcham RA, Carlson WD (1999) Variability of apatite fission-track annealing kinetics. II Crystallographic orientation effects. Am Miner 84:1224-1234

Dumitru TA (1993) A new computer-automated microscope stage system for fission-track analysis. Nucl Tracks Radiat Meas 21:575-580

Dunkl I (2002) Trackkey: a Windows program for calculation and graphical presentation of fission track data. Comput Geosci 28:3-12

Dunkl I, Grasemann B, Frisch W (1998) Thermal effects of exhumation of a metamorphic core complex on hanging wall syn-rift sediments: an example from the Rechnitz Window, Eastern Alps. Tectonophysics 297:31-50

Ehlers TA, Chapman DS (1999) Normal fault thermal regimes: conductive and hydrothermal heat transfer surrounding the Wasatch Fault, Utah. Tectonophysics 312:217-234

Ehlers TA, Armstrong PA, Chapman DS (2001) Normal fault thermal regimes and the interpretation of low-temperature thermochronometers. Phys Earth Planet Inter 126:179-194

Eizenhöfer PR, Glotzbach C, Büttner L, Kley J, Ehlers TA (2021) Turning the orogenic switch: Slab-reversal in the Eastern Alps recorded by low-temperature thermochronology. Geophys Res Lett 48:e2020GL092121

Exner C (1976) Die geologische Position der Magmatite des periadriatischen Lineaments. Verh Geol BA Austria 2:3-64

Farley KA (2000) Helium diffusion from apatite: General behavior as illustrated by Durango fluorapatite. J Geophys Res 105:2903-2914

Farley KA, Wolf RA, Silver LT (1996) The effects of long alpha-stopping distances on (U-Th)/He ages. Geochim Cosmochim Acta 60:4223-4229 
Fitzgerald PG, Reynolds SJ, Stump E, Foster DA, Gleadow AJW (1993) Thermochronologic evidence for timing of denudation and rate of crustal extension of the South Mountains metamorphic core complex and Sierra Estrella, Arizona. Nucl Tracks Radiat Meas 21:555-563

Flowers RM, Ketcham RA, Shuster DL, Farley KA (2009) Apatite (U-Th)/He thermochronometry using a radiation damage accumulation and annealing model. Geochim Cosmochim Acta 73:2347-2365

Foster DA, John BE (1999) Quantifying tectonic exhumation in an extensional orogen with thermochronology: Examples from the southern Basin and Range Province. Geol Soc Lond Spec Publ 154:343-364

Frisch W (1974) Die stratigraphisch tektonische Gliederung der Schieferhülle und die Entwicklung des penninischen Raumes im westlichen Tauernfenster (Gebiet Brenner-Gerlosspass). Mitt Öster Geol G Wien 66-67:9-20

Frisch W (1978) Tectonic progradation and plate tectonic evolution of the Alps. Tectonophysics 60:121-139

Frisch W (1979) Post-Hercynian formations of the western Tauern Window: sedimentological features, depositional environment, and age. Mitt Oster Geol G Wien 71-72:49-63

Frisch W, Kuhlemann J, Dunkl I, Brügel A (1998) Palinspastic reconstruction and topographic evolution of the Eastern Alps during late Tertiary tectonic extrusion. Tectonophysics 297:1-15

Frisch W, Dunkl I, Kuhlemann J (2000) Post-collisional orogen-parallel large-scale extension in the Eastern Alps. Tectonophysics 327:239-265

Froitzheim N, Manatschal G (1996) Kinematics of Jurassic rifting, mantle exhumation, and passive-margin formation in the Austroalpine and Penninic nappes (eastern Switzerland). Geol Soc Am Bull 108:1120-1133

Froitzheim N, Schmid SM, Conti P (1994) Repeated change from crustal shortening to orogen-parallel extension in the Austroalpine units of Graubünden. Eclogae Geol Helv 87:559-612

Fügenschuh B, Seward D, Mancktelow N (1997) Exhumation in a convergent orogen: the western Tauern window. Terra Nova 9:213-217

Fügenschuh B, Mancktelow NS, Seward D (2000) Cretaceous to Neogene cooling and exhumation history of the Oetztal-Stubai basement complex, eastern Alps: a structural and fission track study. Tectonics 19:905-918

Fügenschuh B, Mancktelow N, Schmid S (2012) Comment on Rosenberg and Garcia. Estimating displacement along the Brenner Fault and orogen-parallel extension in the Eastern Alps. Int $\mathbf{J}$ Earth Sci 101:1451-1455

Galbraith RF, Laslett GM (1993) Statistical models for mixed fission track ages. Nucl Tracks Radiat Meas 21:459-470

Gautheron C, Tassan-Got L, Barbarand J, Pagel M (2009) Effect of alpha-damage annealing on apatite (U-Th)/He thermochronology. Chem Geol 266:157-170

Genser J, Neubauer F (1988) Low angle normal faults at the eastern margin of the Tauern Window (Eastern Alps). Mitt Öster Geol G Wien 81:233-243

Gleadow AJW (1981) Fission-track dating methods. What are the real alternatives? Nucl Tracks 5:3-14

Glotzbach C, Reinecker M, Danisik M, Rahn M, Frisch W, Spiegel C (2008) Neogene exhumation history of the Mont Blanc massif, western Alps. Tectonics 27:TC4011

Grasemann B, Mancktelow NS (1993) Two-dimensional thermal modelling of normal faulting: the Simplon Fault Zone, Central Alps, Switzerland. Tectonophysics 225:155-165

Green PF (1981) A new look at statistics in fission-track dating. Nucl Tracks 5:77-86
Grundmann G, Morteani G (1985) The young uplift and thermal history of the central eastern alps (Austria/Italy): evidence from apatite fission track ages. Jb Geol BA 128:197-216

Guenthner WR, Reiners PW, Ketcham RA, Nasdala L, Giester G (2013) Helium diffusion in natural zircon: radiation damage, anisotropy, and the interpretation of zircon (U-Th)/He thermochronology. Am J Sci 313:145-198

Haeuselmann P, Granger DE, Jeannin PY, Lauritzen SE (2007) Abrupt glacial valley incision at 0.8 Ma dated from cave deposits in Switzerland. Geology 35:143-146

Hallet B (1979) A theoretical model of glacial abrasion. J Glaciol 23:39-50

Handy MR, Babist J, Wagner R, Rosenberg C, Konrad M (2005) Decoupling and its relation to strain partitioning in continental lithosphere: insight from the Periadriatic fault system (European Alps). Geol Soc Lond Spec Publ 243:249-276

Handy MR, Schmid SM, Bousquet R, Kissling E, Bernoulli D (2010) Reconciling plate-tectonic reconstructions of Alpine Tethys with the geological-geophysical record of spreading and subduction in the Alps. Earth Sci Rev 102:121-158

Handy MR, Schmid SM, Paffrath M, Friederich W, AlpArray Working Group (2021) European tectosphere and slabs beneath the greater Alpine area-Interpretation of mantle structure in the Alps-Apennines-Pannonian region from teleseismic $V_{p}$ studies. Solid Earth. (preprint)

Hourigan J, Reiners PW, Brandon MT (2005) U-Th zonation-dependent alpha-ejection in (U-Th)/He chronometry. Geochim Cosmochim Acta 69:3349-3365

Hurford AJ, Green PF (1983) The zeta age calibration of fission-track dating. Chem Geol 41:285-317

Hurford AJ (1998) Zeta: the ultimate solution to fission-track analysis calibration or just an interim measure. Solid Earth Sci Lib 10:19-32

Kästle ED, Rosenberg C, Boschi L, Bellahsen N, Meier T, ElSharkawy A (2020) Slab break-offs in the Alpine subduction zone. Int J Earth Sci 109:587-603. https://doi.org/10.1007/ s00531-020-01821-z

Ketcham RA (1996) Thermal models of core-complex evolution in Arizona and New Guinea: implications for ancient cooling paths and present-day heat flow. Tectonics 15:933-951

Ketcham RA (2005) Forward and inverse modeling of low-temperature thermochronometry data. Rev Miner Geochem 58:275-314

Kissling E, Schmid SM, Lippitsch R, Ansorge J, Fügenschuh B (2006) Lithosphere structure and tectonic evolution of the Alpine arc: new evidence from high-resolution teleseismic tomography. Geol Soc Lond Mem 32:129-145

Koons PO, Upton P, Barker AD (2012) The influence of mechanical properties on the link between tectonic and topographic evolution. Geomorphology 137:168-180

Lammerer B (1986) Das Autochthon im westlichen Tauernfenster. Jahrb Geol Bundesanst 129:51-67

Lammerer B, Weger M (1998) Footwall uplift in an orogenic wedge: the Tauern Window in the Eastern Alps of Europe. Tectonophysics 285:213-230

Lammerer B, Gebrande H, Lüschen E, Veselá P (2008) A crustalscale cross-section through the Tauern Window (eastern Alps) from geophysical and geological data. Geol Soc Lond Spec Pub 298:219-229

Laubscher HP (1983a) The late alpine (Periadriatic) intrusions and the Insubric Line. Mem Soc Geol Ital 26:21-30

Laubscher HP (1983b) Detachment, shear and compression in the Central Alps. Geol Soc Am Mem 158:191-211

Leith K, Fox M, Moore JR (2018) Signatures of Late Pleistocene fluvial incision in an Alpine landscape. Earth Planet Sci Lett 483:13-28 
Linzer HG, Decker K, Peresson H, Dell'Mour R, Frisch W (2002) Balancing lateral orogenic float of the Eastern Alps. Tectonophysics 354:211-237

Lippitsch R, Kissling E, Ansorge J (2003) Upper mantle structure beneath the Alpine orogen from high-resolution teleseismic tomography. J Geophys Res 108(B8):2376

Louis S, Luijendijk E, Dunkl I, Person M (2019) Episodic fluid flow in an active fault. Geology 47:938-942

Luijendijk E (2019) Beo v1.0: numerical model of heat flow and lowtemperature thermochronology in hydrothermal systems. Geosci Model Dev Discuss 12:4061-4073

Lünsdorf NK, Dunkl I, Schmidt BC, Ranititsch G, von Eynatten H (2012) The thermal history of the Steinach Nappe (Eastern Alps) during extension along the Brenner Normal Fault system indicated by organic maturation and zircon (U-Th)/He thermochronology. Austrian J Earth Sci 105:17-25

Mancktelow NS, Grasemann B (1997) Time-dependent effects of heat advection and topography on cooling histories during erosion. Tectonophysics 270:167-195

McCallister AT, Taylor MH, Murphy MA, Styron RH, Stockli DF (2014) Thermochronologic constraints on the late Cenozoic exhumation history of the Gurla Mandhata metamorphic core complex, Southwestern Tibet. Tectonics 33:27-52

Milesi G, Solvia R, Monié P, Münch P, Bellanger M, Bruguier O, Bonno M, Taillefer A, Mayolle S (2019) Mapping a geothermal anomaly using apatite (U-Th)/He thermochronology in the Têt fault damage zone, eastern Pyrenees, France. Terra Nova 31:1-8

Most P (2003) Late Alpine cooling histories of tectonic blocks along the central part of the Transalp-Traverse (Inntal-Gadertal): constraints from geochronology. Dissertation University of Tübingen.

Nasdala N, Reiners PW, Garver JI, Kennedy AK, Stern RA, Balan E, Wirth R (2004) Incomplete retention of radiation damage in zircon from Sri Lanka. Am Mineral 89:219-231

Neubauer F, Dallmeyer RD, Dunkl I, Schirnik D (1995) Late Cretaceous exhumation of the metamorphic Gleinalm Dome, Eastern Alps: kinematics, cooling history and sedimentary response in a sinistral wrench corridor. Tectonophysics 242:79-98

Neubauer F, Genser J, Kurz W, Wang X (1999) Exhumation of the Tauern window, Eastern Alps. Phys Chem Earth 24:675-680

Paffrath M, Friederich W, AlpArray working group (2021) Imaging structure and geometry of slabs in the greater Alpine area-A P-wave traveltime tomography using AlpArray Seismic Network data. Solid Earth. (preprint)

Ratschbacher L, Frisch W, Neubauer F, Schmid SM, Neugebauer J (1989) Extension in compressional orogenic belts: the Eastern Alps. Geology 17:404-407

Ratschbacher L, Behrmann JH, Pahr A (1990) Penninic windows at the eastern end of the Alps and their relation to the intra-Carpathian basins. Tectonophysics 172:91-105

Ratschbacher L, Frisch W, Linzer HG, Merlé O (1991) Lateral extrusion in the eastern Alps, Part 2: structural analysis. Tectonics 10:257-271

Reiners PW, Spell TL, Nicolescu S, Zanetti KA (2004) Zircon (U-Th)/ He thermochronometry: He diffusion and comparisons with ${ }^{40} \mathrm{Ar} /{ }^{39} \mathrm{Ar}$ dating. Geochim Cosmochim Acta 68:1857-1887

Reiter F, Freudenthaler C, Hausmann H, Ortner H, Lenhardt W, Brandner R (2018) Active seismotectonic deformation in front of the Dolomites indenter, Eastern Alps. Tectonics 37:4625-4654

Rockenschaub M, Brandner R, Decker K, Priewalder H, Reiter F (2003) Geologie und Tektonik westlich des Wipptales. In: Rockenschaub M (ed) Arbeitstagung 2003 der Geologischen Bundesanstalt, Geologische Kartenblätter 148 Brenner, 175 Sterzing, 79-94. Geol BA, Wien
Rockenschaub M, Nowotny A (2009) Geologische Karte der Republik Österreich 1: 50000, Blatt 148 Brenner. Geol BA, Wien

Rosenberg CL, Garcia S (2011) Estimating displacement along the Brenner Fault and orogen-parallel extension in the Eastern Alps. Int J Earth Sci 100:1129-1145

Rosenberg CL, Brun JP, Gapais D (2004) Indentation model of the Eastern Alps and the origin of the Tauern Window. Geology 32:997-1000

Rosenberg CL, Schneider S, Scharf A, Bertrand A, Hammerschmidt K, Rabaute A, Brun JP (2018) Relating collisional kinematics to exhumation processes in the Eastern Alps. Earth Sci Rev 176:311-344

Scharf A, Handy MR, Favaro S, Schmid SM, Bertrand A (2013) Modes of orogen-parallel stretching and extensional exhumation in response to microplate indentation and roll-back subduction (Tauern Window, Eastern Alps). Int J Earth Sci 102:1627-1654

Schmid SM, Pfiffner OA, Froitzheim N, Schönborn G, Kissling E (1996) Geophysical-geological transect and tectonic evolution of the Swiss-Italian Alps. Tectonics 15:1036-1064

Schmid SM, Fügenschuh B, Kissling E, Schuster R (2004) Tectonic map and overall architecture of the Alpine orogen. Eclogae Geol Helv 97:93-117

Schmid SM, Scharf A, Handy MR, Rosenberg CL (2013) The Tauern Window (Eastern Alps, Austria): a new tectonic map, with crosssections and a tectonometamorphic synthesis. Swiss J Geosci 106:1-32

Schmidegg O (1964) Die Ötztaler Schubmasse und ihre Umgebung. Verh Geol BA 1:27-47

Schneider S, Hammerschmidt K, Rosenberg CL, Gerdes A, Frei D, Bertrand A (2015) U-Pb ages of apatite in the western Tauern Window (Eastern Alps): tracing the onset of collisionrelated exhumation in the European plate. Earth Planet Sci Lett 418:53-65

Schuster R, Koller F, Hoeck V, Hoinkes G, Bousquet R (2004) Explanatory notes to the map Metamorphic Structure of the Alps. Mitt Öster Min G Wien 149:175-199

Seguinot J, Ivy-Ochs S, Jouvet G, Huss M, Funk M, Preusser F (2018) Modelling last glacial cycle ice dynamics in the Alps. Cryosphere 12:3265-3285

Selverstone J (1985) Petrologic constraints on imbrication, metamorphism, and uplift in the SW Tauern Window, Eastern Alps. Tectonics 4:687-704

Selverstone J (1988) Evidence for east-west crustal extension in the eastern Alps. Implications for the unroofing history of the Tauern Window. Tectonics 7:87-105

Selverstone J, Spear FS, Franz G, Morteani G (1984) High-pressure metamorphism in the SW Tauern Window, Austria: P-T paths from hornblende-kyanite-staurolite schists. J Petrol 25:501-531

Seward D, Vanderhaeghe O, Siebenaller L, Thomson S, Hibsch C, Zingg A, Holzner P, Ring U, Duchêne S (2009) Cenozoic tectonic evolution of Naxos Island through a multi-faceted approach of fission-track analysis. Geol Soc Lond Spec Pub 321:179-196

Stampfli GM (2000) Tethyan oceans. Geol Soc Lond Spec Publ 173:1-23

Stüwe K, White L, Brown R (1994) The influence of eroding topography on steady-state isotherms: applications to fission track analysis. Earth Planet Sci Lett 124:63-74

Styron R, Taylor M, Sundell K, Stockli DF, Oalmann JAG, Möller A, McCallister AT, Liu D, Ding L (2013) Miocene initiation and acceleration of extension in the South Lunggar rift, western Tibet. Evolution of an active detachment system from structural mapping and (U-Th)/He thermochronology. Tectonics 32:880-907

Tagami T (2005) Zircon fission-track thermochronology and applications to fault studies. Rev Miner Geochem 58:95-122 
Termier P (1903) Les nappes des Alpes Orientales et la Synthese des Alpes. Soc Géol Fr Mém 4:711-765

Töchterle A, Brandner R, Reiter F (2011) Strain partitioning on major fault zones in the northwestern Tauern Window-insights from the investigations to the Brenner Base Tunnel. Austrian J Earth Sci 104:15-35

Tollmann A (1962) Der Baustil der tieferen tektonischen Einheiten der Ostalpen. Geol Rundschau 52:226-237

Trümpy R (1960) Paleotectonic evolution of the Central and Western Alps. Geol Soc Am Bull 71:843-908

Valla PG, Shuster DL, van der Beek PA (2011) Significant increase in relief of the European Alps during mid-Pleistocene glaciations. Nat Geosci 4:688-692

Veselá P, Lammerer B (2008) The Pfitsch-Mörchner Basin, an example of the post-Variscan sedimentary evolution in the Tauern Window (Eastern Alps). Swiss J Geosci 101:73-88

Villa IM (1998) Isotopic closure. Terra Nova 10:42-47

von Blanckenburg F, Davies JH (1995) Slab breakoff. A model for syncollisional magmatism and tectonics in the Alps. Tectonics 14:120-131

von Blanckenburg F, Villa IM, Baur H, Morteani G, Steiger RH (1989) Time calibration of a PT-path from the Western Tauern Window, Eastern Alps: the problem of closure temperatures. Contrib Miner Petrol 101:1-11
Wawrzyniec T, Selverstone J, Axen GJ (1999) Correlations between fluid composition and deep-seated structural style in the footwall of the Simplon low-angle normal fault, Switzerland. Geology 27:715-718

Wolff R, Hetzel R, Dunkl I, Bröcker M, Xu Q, Anczkiewicz AA (2019) High-angle normal faulting at the Tangra Yumco graben (southern Tibet) since $\sim 15$ Ma. J Geology 127:15-36

Wolff R, Hetzel R, Dunkl I, Anczkiewicz AA, Pomella H (2020) Fast cooling of normal-fault footwalls: rapid fault slip or thermal relaxation? Geology 48:333-337

Wölfler A, Kurz W, Danišík M, Rabitsch R (2010) Dating of fault zone activity by apatite fission track and apatite (U-Th)/He thermochronometry: a case study from the Lavanttal fault system (Eastern Alps). Terra Nova 22:274-282

York D (1966) Least square fitting of a straight line. Can J Phys 44:1079-1086

Zaun P, Wagner GA (1985) Fission track stability in zircon under geological conditions. Nucl Tracks Radiat Meas 10:303-307

Zeitler PK, Enkelmann E, Thomas JB, Watson EB, Ancuta LD, Idleman BD (2017) Solubility and trapping of helium in apatite. Geochim Cosmochim Acta 209:1-8 